\title{
Evaluating the sensitivity of radical chemistry and ozone formation to ambient VOCs and $\mathrm{NO}_{x}$ in Beijing
}

\author{
Lisa K. Whalley ${ }^{1,2}$, Eloise J. Slater ${ }^{1}$, Robert Woodward-Massey ${ }^{1, a}$, Chunxiang Ye ${ }^{1, \text { a }}$, James D. Lee ${ }^{3,4}$, Freya Squires ${ }^{4}$, \\ James R. Hopkins ${ }^{3,4}$, Rachel E. Dunmore ${ }^{4}$, Marvin Shaw ${ }^{3,4}$, Jacqueline F. Hamilton ${ }^{4}$, Alastair C. Lewis ${ }^{3,4}$,

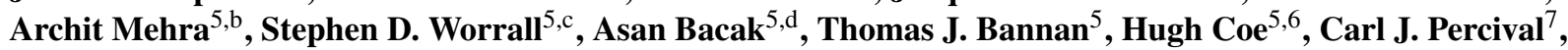 \\ Bin Ouyang $^{8, e}$, Roderic L. Jones ${ }^{8}$, Leigh R. Crilley ${ }^{\text {, f }}$, Louisa J. Kramer ${ }^{9}$, William J. Bloss ${ }^{9}$, Tuan Vu ${ }^{9}$, \\ Simone Kotthaus ${ }^{10,11}$, Sue Grimmond ${ }^{10}$, Yele Sun ${ }^{12}$, Weiqi Xu ${ }^{12}$, Siyao Yue ${ }^{12}$, Lujie Ren ${ }^{12}$, W. Joe F. Acton ${ }^{13}$, \\ C. Nicholas Hewitt ${ }^{13}$, Xinming Wang ${ }^{14}$, Pingqing $\mathbf{F u}^{15}$, and Dwayne E. Heard ${ }^{1}$ \\ ${ }^{1}$ School of Chemistry, University of Leeds, Leeds, LS2 9JT, UK \\ ${ }^{2}$ National Centre for Atmospheric Science, University of Leeds, Leeds, LS2 9JT, UK \\ ${ }^{3}$ National Centre for Atmospheric Science, University of York, Heslington, York, YO10 5DD, UK \\ ${ }^{4}$ Wolfson Atmospheric Chemistry Laboratories, Department of Chemistry, University of York, \\ Heslington, York, YO10 5DD, UK \\ ${ }^{5}$ Centre for Atmospheric Science, School of Earth and Environmental Sciences, The University of Manchester, \\ Manchester, M13 9PL, UK \\ ${ }^{6}$ National Centre for Atmospheric Science, University of Manchester, Manchester, M13 9PL, UK \\ ${ }^{7}$ Jet Propulsion Laboratory, California Institute of Technology, Pasadena, CA, USA \\ ${ }^{8}$ Department of Chemistry, University of Cambridge, Cambridge, UK \\ ${ }^{9}$ School of Geography, Earth and Environmental Sciences, University of Birmingham, Birmingham, B15 2TT, UK \\ ${ }^{10}$ Department of Meteorology, University of Reading, Reading, UK \\ ${ }^{11}$ Institut Pierre Simon Laplace, École Polytechnique, Palaiseau, France \\ ${ }^{12}$ State Key Laboratory of Atmospheric Boundary Layer Physics and Atmospheric Chemistry, Institute for Atmospheric \\ Physics, Chinese Academy of Sciences, 40 Huayanli, Chaoyang District, Beijing 100029, China \\ ${ }^{13}$ Lancaster Environment Centre, Lancaster University, Lancaster, LA1 4YW, UK \\ ${ }^{14}$ State Key Laboratory of Organic Geochemistry, Guangzhou Institute of Geochemistry, Chinese Academy of Sciences, 511 \\ Kehua Street, Wushan, Tianhe District, Guangzhou, GD 510640, China \\ ${ }^{15}$ Institute of Surface-Earth System Science, Tianjin University, Tianjin 300072, China \\ ${ }^{a}$ now at: College of Environmental Sciences and Engineering, Peking University, Beijing 100871, China \\ ${ }^{b}$ now at: Faculty of Science and Engineering, University of Chester, Chester, CH2 4NU, UK \\ ${ }^{c}$ now at: Aston Institute of Materials Research, School of Engineering and Applied Science, \\ Aston University, Birmingham, B4 7ET, UK \\ ${ }^{d}$ now at: Turkish Accelerator \& Radiation Laboratory, Ankara University Institute of Accelerator Technologies, Atmospheric \\ and Environmental Chemistry Laboratory, Gölbaşı Campus, Ankara, Turkey \\ enow at: Lancaster Environment Centre, Lancaster University, Lancaster, LA1 4YW, UK \\ ${ }^{f}$ now at: Department of Chemistry, York University, Toronto, ON, M3J 1P3, Canada
}

Correspondence: Lisa Whalley (1.k.whalley@leeds.ac.uk)

Received: 28 July 2020 - Discussion started: 3 September 2020

Revised: 4 December 2020 - Accepted: 21 December 2020 - Published: 12 February 2021 
Abstract. Measurements of $\mathrm{OH}, \mathrm{HO}_{2}$, complex $\mathrm{RO}_{2}$ (alkene- and aromatic-related $\mathrm{RO}_{2}$ ) and total $\mathrm{RO}_{2}$ radicals taken during the integrated Study of AIR Pollution PROcesses in Beijing (AIRPRO) campaign in central Beijing in the summer of 2017, alongside observations of $\mathrm{OH}$ reactivity, are presented. The concentrations of radicals were elevated, with $\mathrm{OH}$ reaching up to $2.8 \times 10^{7}$ molecule $\mathrm{cm}^{-3}$, $\mathrm{HO}_{2}$ peaking at $1 \times 10^{9}$ molecule $\mathrm{cm}^{-3}$ and the total $\mathrm{RO}_{2}$ concentration reaching $5.5 \times 10^{9}$ molecule $\mathrm{cm}^{-3}$. OH reactivity $(k(\mathrm{OH}))$ peaked at $89 \mathrm{~s}^{-1}$ during the night, with a minimum during the afternoon of $\approx 22 \mathrm{~s}^{-1}$ on average. An experimental budget analysis, in which the rates of production and destruction of the radicals are compared, highlighted that although the sources and sinks of $\mathrm{OH}$ were balanced under high $\mathrm{NO}$ concentrations, the $\mathrm{OH}$ sinks exceeded the known sources (by $15 \mathrm{ppbvh}^{-1}$ ) under the very low NO conditions $(<0.5 \mathrm{ppbv})$ experienced in the afternoons, demonstrating a missing $\mathrm{OH}$ source consistent with previous studies under high volatile organic compound (VOC) emissions and low NO loadings. Under the highest NO mixing ratios (104 ppbv), the $\mathrm{HO}_{2}$ production rate exceeded the rate of destruction by $\approx 50 \mathrm{ppbvh}^{-1}$, whilst the rate of destruction of total $\mathrm{RO}_{2}$ exceeded the production by the same rate, indicating that the net propagation rate of $\mathrm{RO}_{2}$ to $\mathrm{HO}_{2}$ may be substantially slower than assumed. If just $10 \%$ of the $\mathrm{RO}_{2}$ radicals propagate to $\mathrm{HO}_{2}$ upon reaction with $\mathrm{NO}$, the $\mathrm{HO}_{2}$ and $\mathrm{RO}_{2}$ budgets could be closed at high $\mathrm{NO}$, but at low NO this lower $\mathrm{RO}_{2}$ to $\mathrm{HO}_{2}$ propagation rate revealed a missing $\mathrm{RO}_{2}$ sink that was similar in magnitude to the missing $\mathrm{OH}$ source. A detailed box model that incorporated the latest Master Chemical Mechanism (MCM3.3.1) reproduced the observed $\mathrm{OH}$ concentrations well but over-predicted the observed $\mathrm{HO}_{2}$ under low concentrations of $\mathrm{NO}(<1 \mathrm{ppbv})$ and under-predicted $\mathrm{RO}_{2}$ (both the complex $\mathrm{RO}_{2}$ fraction and other $\mathrm{RO}_{2}$ types which we classify as simple $\mathrm{RO}_{2}$ ) most significantly at the highest NO concentrations. The model also under-predicted the observed $k(\mathrm{OH})$ consistently by $\approx 10 \mathrm{~s}^{-1}$ across all $\mathrm{NO}_{x}$ levels, highlighting that the good agreement for $\mathrm{OH}$ was fortuitous due to a cancellation of missing $\mathrm{OH}$ source and sink terms in its budget. Including heterogeneous loss of $\mathrm{HO}_{2}$ to aerosol surfaces did reduce the modelled $\mathrm{HO}_{2}$ concentrations in line with the observations but only at NO mixing ratios $<0.3 \mathrm{ppbv}$. The inclusion of $\mathrm{Cl}$ atoms, formed from the photolysis of nitryl chloride, enhanced the modelled $\mathrm{RO}_{2}$ concentration on several mornings when the $\mathrm{Cl}$ atom concentration was calculated to exceed $1 \times 10^{4}$ atoms $\mathrm{cm}^{-3}$ and could reconcile the modelled and measured $\mathrm{RO}_{2}$ concentrations at these times. However, on other mornings, when the $\mathrm{Cl}$ atom concentration was lower, large under-predictions in total $\mathrm{RO}_{2}$ remained. Furthermore, the inclusion of $\mathrm{Cl}$ atom chemistry did not enhance the modelled $\mathrm{RO}_{2}$ beyond the first few hours after sunrise and so was unable to resolve the modelled under-prediction in $\mathrm{RO}_{2} \mathrm{ob}-$ served at other times of the day. Model scenarios, in which missing VOC reactivity was included as an additional reac- tion that converted $\mathrm{OH}$ to $\mathrm{RO}_{2}$, highlighted that the modelled $\mathrm{OH}, \mathrm{HO}_{2}$ and $\mathrm{RO}_{2}$ concentrations were sensitive to the choice of $\mathrm{RO}_{2}$ product. The level of modelled to measured agreement for $\mathrm{HO}_{2}$ and $\mathrm{RO}_{2}$ (both complex and simple) could be improved if the missing $\mathrm{OH}$ reactivity formed a larger $\mathrm{RO}_{2}$ species that was able to undergo reaction with $\mathrm{NO}$, followed by isomerisation reactions reforming other $\mathrm{RO}_{2}$ species, before eventually generating $\mathrm{HO}_{2}$. In this work an $\alpha$-pinene-derived $\mathrm{RO}_{2}$ species was used as an example. In this simulation, consistent with the experimental budget analysis, the model underestimated the observed $\mathrm{OH}$, indicating a missing $\mathrm{OH}$ source. The model uncertainty, with regards to the types of $\mathrm{RO}_{2}$ species present and the radicals they form upon reaction with $\mathrm{NO}\left(\mathrm{HO}_{2}\right.$ directly or another $\mathrm{RO}_{2}$ species), leads to over an order of magnitude less $\mathrm{O}_{3}$ production calculated from the predicted peroxy radicals than calculated from the observed peroxy radicals at the highest NO concentrations. This demonstrates the rate at which the larger $\mathrm{RO}_{2}$ species propagate to $\mathrm{HO}_{2}$, to another $\mathrm{RO}_{2}$ or indeed to $\mathrm{OH}$ needs to be understood to accurately simulate the rate of ozone production in environments such as Beijing, where large multifunctional VOCs are likely present.

\section{Introduction}

Owing to strict emission controls being implemented across China, a reduction in the levels of $\mathrm{PM}_{10}, \mathrm{PM}_{2.5}$ and $\mathrm{SO}_{2}$ has been observed in the country since 2013 (Huang et al., 2018). Similar reductions in these primary pollutants are echoed in other countries across the globe. In the United States this reduction in primary emissions is reflected in $\mathrm{a} \approx 0.4 \mathrm{ppbv} \mathrm{yr}^{-1}$ reduction in peak $\mathrm{O}_{3}$ (He et al., 2020). In China, however, despite reductions in primary emissions, the concentration of ground-level ozone gradually increased between 20132017 (Huang et al., 2018). The highest peak ozone concentrations in China are observed in the Beijing area (T. Wang et al., 2017), where the highest $\mathrm{O}_{3}$ mixing ratio of $286 \mathrm{ppbv}$ was recorded at a rural site $50 \mathrm{~km}$ north of the centre (Wang et al., 2006). During the Beijing Olympic Games, despite emission controls, hourly ozone mixing ratios between 160 to $180 \mathrm{ppbv}$ were frequently observed in central Beijing (Wang et al., 2010). Ozone is a secondary pollutant, primarily formed in the troposphere via $\mathrm{OH}$-initiated volatile organic compound (VOC) oxidation in the presence of $\mathrm{NO}_{x}$. $\mathrm{O}_{3}$ concentrations in megacities worldwide frequently exceed regulatory limits during the summer months, with elevated ozone concentrations shown to have negative impacts on human and crop health. The radical species, $\mathrm{OH}, \mathrm{HO}_{2}$ and $\mathrm{RO}_{2}$, play a central role in the catalytic photochemical cycle which removes primary emissions and leads to ozone formation. The $\mathrm{OH}$ radical initiates the oxidation of VOCs, leading to the formation of peroxy radicals $\left(\mathrm{HO}_{2}\right.$ and $\mathrm{RO}_{2}$ ). Peroxy radicals oxidise $\mathrm{NO}$ to $\mathrm{NO}_{2}$, which photoly- 
ses and generates ozone. Under high $\mathrm{NO}_{x}$ conditions, $\mathrm{OH}$ preferentially reacts with $\mathrm{NO}_{2}$, and both peroxy radical production (via VOC oxidation) and, in turn, ozone production decrease. This non-linear relationship between ozone and $\mathrm{NO}_{x}$ complicates efforts to reduce the ambient ozone levels as, in $\mathrm{NO}_{x}$-saturated environments, reductions in $\mathrm{NO}_{x}$ can lead to increases in the rate of ozone production (e.g. Bigi and Harrison, 2010). Furthermore, a number of studies have highlighted that efforts to reduce PM have the potential to exacerbate $\mathrm{O}_{3}$ due to concomitant increases in $\mathrm{HO}_{2}$ caused by a reduction in the heterogeneous loss of $\mathrm{HO}_{2}$ to aerosol surfaces ( $\mathrm{Li}$ et al., 2019), although there is continued debate on the magnitude of this effect from field studies (Tan et al., 2020). As well as the central role OH plays in photochemical ozone formation, $\mathrm{OH}$ promotes the formation of secondary aerosols (sulfate, nitrate and secondary organic aerosols, SOA), which have negative impacts on human health (Chen et al., 2013). Large, complex $\mathrm{RO}_{2}$ radicals are precursors to highly oxidised molecules (HOMs) (Ehn et al., 2014), which have also been shown to condense and contribute to SOA (Mohr et al., 2019). In China, the fraction of PM attributed to secondary aerosols is significant (between $44 \%-71 \%$, Huang et al., 2014), and so understanding the oxidation chemistry which converts primary emissions to secondary aerosols is an ongoing challenge. There has been an increasing growth in photochemical oxidant studies conducted in China, where radical observations have been performed over the past decade, with the PKU and Juelich groups leading these efforts. The first radical observations took place in the summer of 2006, with observations made in the Pearl River Delta (PRD) region (Hofzumahaus et al., 2009; Lu et al., 2012; PRIDE-PRD-2006) and also in suburban Beijing (Lu et al., 2013; CARE-Beijing 2006). These campaigns revealed a strong atmospheric oxidation capacity, with elevated levels of $\mathrm{OH}$ and $\mathrm{HO}_{2}$ in these regions, with $\mathrm{OH}$ concentrations up to $2.6 \times 10^{7}$ molecule $\mathrm{cm}^{-3}$ and $\mathrm{HO}_{2}$ concentrations up to $2.5 \times 10^{9}$ molecule $\mathrm{cm}^{-3}$ reported (Lu et al., 2012). Even during the wintertime, under low levels of solar radiation, concentrations of $\mathrm{OH}$ can reach $3 \times 10^{6}$ molecule $\mathrm{cm}^{-3}$ in Beijing (Slater et al., 2020), which is similar to the $\mathrm{OH}$ concentrations observed in other urban centres in European cities during the summer months (Whalley et al., 2018). Similar to findings from radical observations and subsequent modelling activities in forested regions (Whalley et al., 2011), which are characterised by high VOC emissions and relatively low $\mathrm{NO}_{x}$ concentrations, the observations and modelling studies in China in summer (Hofzumahaus et al., 2009; Lu et al., 2012; Lu et al., 2013) revealed that the high $\mathrm{OH}$ concentrations could only be explained if an additional source of $\mathrm{OH}$, from recycling peroxy radicals to $\mathrm{OH}$, was added to the model. An updated isoprene scheme (Peeters et al., 2009, 2014), which included isomerisation reactions of the isoprene-derived $\mathrm{RO}_{2}$ radicals, was unable to reconcile the $\mathrm{OH}$ observations, however. In a subsequent field study conducted in the PRD region (Tan et al.,
2019), $\mathrm{RO}_{2}$ observations were made using the $\mathrm{RO}_{x}$ laserinduced fluorescence (LIF) technique alongside $\mathrm{OH}, \mathrm{HO}_{2}$ and $\mathrm{OH}$ reactivity, allowing an experimental budget analysis for $\mathrm{OH}, \mathrm{HO}_{2}, \mathrm{RO}_{2}$ and $\mathrm{RO}_{x}\left(\mathrm{OH}+\mathrm{HO}_{2}+\mathrm{RO}_{2}\right)$ to be performed. The analysis demonstrated a missing $\mathrm{OH}$ source of 4-6 ppbv h${ }^{-1}$ and a missing $\mathrm{RO}_{2}$ sink that was similar in magnitude and, hence, supports the hypothesis of a missing mechanism that converts $\mathrm{RO}_{2}$ species to $\mathrm{OH}$ under low $\mathrm{NO}$ conditions. The authors calculated that the unknown $\mathrm{RO}_{2}$ to $\mathrm{OH}$ conversion that does not involve reaction with $\mathrm{NO}$ (and, therefore, does not lead to the formation of ozone) reduced ozone production by $30 \mathrm{ppbv} \mathrm{d}^{-1}$, demonstrating that knowledge of the branching ratio between the competitive reactions that $\mathrm{RO}_{2}$ radicals undergo (bimolecular reaction with $\mathrm{NO}$ or unimolecular isomerisation), as well as the overall VOC oxidation rate, is important when determining in situ ozone production.

In a recent campaign conducted at a rural site in the North China Plain (Tan et al., 2017), during periods in which NO mixing ratios were below 300 pptv, an additional $\mathrm{OH}$ recycling mechanism was again needed to reconcile the $\mathrm{OH}$ concentrations observed. The modelled $\mathrm{RO}_{2}$ concentrations were in good agreement with those observed under low NO concentrations typically experienced during the afternoon; however, the model under-predicted the $\mathrm{RO}_{2}$ concentrations by a factor of 3-5 at the higher NO mixing ratios ( $>1 \mathrm{ppbv}$ ) that were observed during the mornings. Additional sources of $\mathrm{RO}_{2}$ from the photolysis of $\mathrm{ClNO}_{2}$ and subsequent reactions of $\mathrm{Cl}$ atoms with VOCs, as well as $\mathrm{RO}_{2}$ from the missing reactivity determined, could explain $\approx 10 \%-20 \%$ of the model under-prediction but could not fully resolve the missing $\mathrm{RO}_{2}$ source of $2 \mathrm{ppbvh}^{-1}$ under the high $\mathrm{NO}$ conditions. As a result, the model was found to under-predict the net in situ chemical ozone production by $20 \mathrm{ppbvd}^{-1}$. In London, during the ClearfLo campaign (Whalley et al., 2018), under higher NO mixing ratios ( $>3 \mathrm{ppbv}$ ) a box model constrained to the Master Chemical Mechanism (MCM3.2) was found to increasingly under-predict the $\mathrm{RO}_{2}$ concentrations observed with $\mathrm{NO}_{x}$, and, as a consequence, the rate of ozone production calculated from the modelled peroxy radical concentrations was up to an order of magnitude lower than the ozone production rate calculated from the observed peroxy radicals. The model was able to reproduce the observed levels of $\mathrm{HO}_{2}$ under the high $\mathrm{NO}$ concentrations but over-predicted $\mathrm{HO}_{2}$ concentrations when NO mixing ratios were below $1 \mathrm{ppbv}$, and modest under-predictions of $\mathrm{OH}$ were observed under low NO conditions, which demonstrated uncertainties in radical cycling at low NO. Conversely, in other urban studies, models were found to increasingly under-predict $\mathrm{HO}_{2}$ as $\mathrm{NO}_{x}$ levels increased beyond $\approx 1$ ppbv (Martinez et al., 2003; Ren et al., 2013; Brune et al., 2016), although in some of these earlier studies, the $\mathrm{HO}_{2}$ observations may have been influenced by an $\mathrm{RO}_{2}$ interference (Whalley et al., 2013). Understanding the cause of the model failure under different $\mathrm{NO}$ regimes in urban centres is critical to be able to accurately 
predict ozone production and to determine ozone abatement strategies that can be implemented to successfully reduce ozone levels. Measurements of $\mathrm{OH}, \mathrm{HO}_{2}$ and $\mathrm{RO}_{2}$ as well as $\mathrm{OH}$ reactivity are necessary to fully explore a model's skill to capture the entire atmospheric oxidation cycle and to begin to identify mechanisms that can reconcile the concentration of all radical species.

The integrated Study of AIR Pollution PROcesses in Beijing (AIRPRO) project involved two intensive measurement periods that took place in central Beijing during the winter of 2016 and during the following summer of 2017 and was part of the larger Air Pollution and Human Health (APHH) programme. APHH had the overall aim of better understanding the sources, atmospheric transformations and health impacts of air pollutants in Beijing to improve air quality forecasting capabilities (Shi et al., 2019). In this paper the observations of $\mathrm{OH}, \mathrm{HO}_{2}, \mathrm{RO}_{2}$ and $\mathrm{OH}$ reactivity from the summer period are compared to a detailed zero dimensional box model run with the latest Master Chemical Mechanism (MCM3.3.1), and an experimental budget analysis is performed on all radical species. The overall objective of this research was to test the model's ability to reproduce the radical concentrations and, through the budget analysis, investigate the balance between radical production and destruction rates. Following on from the results of earlier radical observation and modelling studies conducted in urban regions, this research will investigate if there are missing radical sources and sinks under different NO regimes and investigate new chemistry that may improve model predictions. We will assess how uncertainties in the model mechanism influence the rate of in situ ozone production in an environment with large and complex VOC emissions and under highly variable $\mathrm{NO}_{x}$ concentrations.

\section{Experimental}

\subsection{Site description}

The observations took place in central Beijing at the Institute of Atmospheric Physics (IAP), which is part of the Chinese Academy of Sciences. The site was located between the third and fourth north ring roads in Beijing and was within $150 \mathrm{~m}$ of several busy roads. All instrumentation was located in close proximity within nine shipping containers that were placed on a grassed area surrounding a large $(325 \mathrm{~m})$ meteorological tower. Further details of the measurement site and an overview of all the instrumentation that was run during the campaign can be found in Shi et al. (2019).

\subsection{FAGE instrumentation}

The University of Leeds fluorescence assay by gas expansion (FAGE) instrument was deployed at the IAP site and made measurements of $\mathrm{OH}, \mathrm{HO}_{2}, \mathrm{RO}_{2}$ radicals and $\mathrm{OH}$ reactivity $(k(\mathrm{OH}))$. The instrumental set-up was analogous to that used during the ClearfLo project (see Whalley et al., 2016, for the
$k(\mathrm{OH})$ instrument description and Whalley et al., 2018, for the $\mathrm{OH}, \mathrm{HO}_{2}$ and $\mathrm{RO}_{2}$ instrument details) and also the winter AIRPRO project (Slater et al., 2020) and so is only briefly overviewed here. Two detection cells, the $\mathrm{HO}_{x}$ cell and the $\mathrm{RO}_{x}$ LIF cell, were located on the roof of the Leeds FAGE shipping container at a sampling height of $3.5 \mathrm{~m}$. The $k(\mathrm{OH})$ instrument, which was housed inside the container, alongside all other FAGE instrument components (including the laser system), drew air from close by the radical detection cells via a $1 / 2$ in. Teflon line. The $\mathrm{HO}_{x}$ cell made sequential measurements of $\mathrm{OH}$ and then the sum of $\mathrm{OH}+\mathrm{HO}_{2}$, by the addition of $\mathrm{NO}$ (Messer, $99.95 \%$ ), which titrated $\mathrm{HO}_{2}$ to $\mathrm{OH}$ for detection by laser-induced fluorescence (LIF). In the $\mathrm{RO}_{x}$ LIF reactor, which is an $83 \mathrm{~cm}$ long, $6.4 \mathrm{~cm}$ internal diameter flow tube, in $\mathrm{HO}_{x}$ mode, a flow of $\mathrm{CO}(10 \%$ in $\mathrm{N}_{2}$ ) was added just beneath the sampling inlet, and this rapidly converted any ambient $\mathrm{OH}$ sampled to $\mathrm{HO}_{2}$. Within the $\mathrm{RO}_{x}$ LIF FAGE cell, a continuous flow of NO $(99.95 \%)$ titrated ambient $\mathrm{HO}_{2}$, the converted $\mathrm{OH}$ and also a large percentage of complex $\mathrm{RO}_{2}$ radicals (see below) to $\mathrm{OH}$ for detection. In $\mathrm{RO}_{x}$ mode, a total $\mathrm{RO}_{2}+\mathrm{HO}_{2}+\mathrm{OH}$ measurement was made by addition of a dilute flow of NO $(500 \mathrm{ppmv}$ in $\mathrm{N}_{2}$ ) alongside the $\mathrm{CO}$, which promoted the conversion of all $\mathrm{HO}_{2}$ and $\mathrm{RO}_{2}$ radicals to $\mathrm{OH}$; the $\mathrm{OH}$ formed was rapidly reconverted to $\mathrm{HO}_{2}$ by reaction with $\mathrm{CO}$. Within the $\mathrm{RO}_{x}$ LIF FAGE cell, the $\mathrm{HO}_{2}$ was titrated back to $\mathrm{OH}$, by reaction with NO, for detection. Using the methodology outlined in Whalley et al. (2013), the sensitivity of both the $\mathrm{HO}_{x}$ and $\mathrm{RO}_{x}$ LIF FAGE cells towards $\mathrm{HO}_{2}$ and complex $\mathrm{RO}_{2}$ species was assessed before the instrument was deployed to Beijing by sampling isoprene-derived $\mathrm{RO}_{2}$; the sensitivity of the $\mathrm{HO}_{x}$ cell towards other $\mathrm{RO}_{2}$ types such as those derived from ethene, methanol and propane has been previously conducted (Whalley et al., 2013) and compared well with model-predicted sensitivities. The sensitivity of the $\mathrm{RO}_{x}$ LIF instrument has also been assessed previously towards a range of $\mathrm{RO}_{2}$ types deriving from methane, isoprene, ethene, toluene, butane and cyclohexane and, again, compared well with model-predicted sensitivities (Whalley et al., 2018). "Complex $\mathrm{RO}_{2}$ " refers to any $\mathrm{RO}_{2}$ species (primarily those derived from alkene and aromatic hydrocarbons) that have the potential to decompose into $\mathrm{OH}$ in the presence of $\mathrm{NO}$ on the timescale of the FAGE residence time and, therefore, have the potential to act as an $\mathrm{HO}_{2}$ interference. The NO flow in the $\mathrm{HO}_{x}$ cell was kept low to minimise the conversion efficiency of complex $\mathrm{RO}_{2}$ to $\mathrm{OH}$, and the conversion efficiency was found to be $<5 \%$ when isoprene-derived $\mathrm{RO}_{2}$ radicals were sampled. In the $\mathrm{RO}_{x}$ LIF FAGE cell, a higher NO flow was employed to promote the conversion of complex $\mathrm{RO}_{2}$ to $\mathrm{OH}$, enabling $89 \%$ of isoprene-derived $\mathrm{RO}_{2}$ radicals to be detected. From the relative sensitivities of the two cells to $\mathrm{OH}, \mathrm{HO}_{2}$ and complex $\mathrm{RO}_{2}$, and by subtraction of complex $\mathrm{RO}_{2}$ from total $\mathrm{RO}_{2}$, the concentration of $\mathrm{RO}_{2}$ species that do not act as an $\mathrm{HO}_{2}$ interference ("simple $\mathrm{RO}_{2}$ ") has been derived. 
For the entirety of the campaign, the $\mathrm{HO}_{x}$ cell was equipped with an inlet pre-injector (IPI; Woodward-Massey et al., 2020), which, by injection of propane into the ambient air stream directly above the $\mathrm{HO}_{x}$ inlet, removes ambient $\mathrm{OH}$ and enables a background measurement from laser scatter, solar scatter and detector dark counts (and potentially any cell-generated $\mathrm{OH}$ ) to be determined whilst the laser is tuned to the $\mathrm{OH}$ transition. The subtraction of this background signal from the ambient $\mathrm{OH}$ signal provides the $\mathrm{OH}_{\mathrm{CHEM}}$ measurement, which can be compared to the traditional $\mathrm{OH}_{\text {WAVE }}$ measurement in which the background signal (from laser scatter, solar scatter and detector dark counts only) is determined by tuning the laser wavelength away from the $\mathrm{OH}$ transition. Differences between $\mathrm{OH}_{\mathrm{CHEM}}$ and $\mathrm{OH}_{\text {WAVE }}$ can highlight the presence of an $\mathrm{OH}$ interference. During the summer AIRPRO campaign, once the known $\mathrm{OH}$ interference deriving from laser photolysis of ambient ozone and the subsequent reaction of photogenerated $\mathrm{O}\left({ }^{1} \mathrm{D}\right)$ atoms with ambient $\mathrm{H}_{2} \mathrm{O}$ (v) were accounted for (WoodwardMassey et al., 2020), the agreement between $\mathrm{OH}_{\mathrm{CHEM}}$ and $\mathrm{OH}_{\text {WAVE }}$ was generally very good (see Fig. 14 in WoodwardMassey et al., 2020). However, on five afternoons when ozone was extremely elevated ( $>100 \mathrm{ppbv}$ ) and $\mathrm{OH}$ concentrations were high $\left(>1 \times 10^{7} \mathrm{~cm}^{-3}\right), \mathrm{OH}_{\mathrm{WAVE}}$ was greater than $\mathrm{OH}_{\mathrm{CHEM}}$ (by up to $18 \%$ ), highlighting a small unknown interference under these very perturbed conditions. In all the model-measurement comparisons presented in Sect. 3, the interference-free $\mathrm{OH}_{\mathrm{CHEM}}$ measurement is used.

Both detection cells were calibrated every $3 \mathrm{~d}$ during the campaign by photolysis of a known concentration of $\mathrm{H}_{2} \mathrm{O}$ (v) at $185 \mathrm{~nm}$ with a $\mathrm{Hg}$ lamp in synthetic air (Messer, Air Grade Zero 2) within a turbulent flow tube, which generates an equal concentration of $\mathrm{OH}$ and $\mathrm{HO}_{2}$ (Whalley et al., 2018). The product of the photon flux at $185 \mathrm{~nm}$ (determined by $\mathrm{N}_{2} \mathrm{O}$ actinometry before and after the instrument was deployed to Beijing; Commane et al., 2010), [ $\left.\mathrm{H}_{2} \mathrm{O}\right]$ and irradiance time, was used to calculate $[\mathrm{OH}]$ and $\left[\mathrm{HO}_{2}\right]$. For calibration of $\mathrm{RO}_{2}$ concentrations, methane (Messer, Grade 5, 99.99\%) was added to the humidified air flow in sufficient quantity to completely convert $\mathrm{OH}$ to $\mathrm{CH}_{3} \mathrm{O}_{2}$. The median limit of detection (LOD) during the campaign was $6.1 \times 10^{5}$ molecule $\mathrm{cm}^{-3}$ for $\mathrm{OH}, 2.8 \times 10^{6}$ molecule $\mathrm{cm}^{-3}$ for $\mathrm{HO}_{2}$ and $7.2 \times 10^{6}$ molecule $\mathrm{cm}^{-3}$ for $\mathrm{CH}_{3} \mathrm{O}_{2}$ at a typical laser power of $11 \mathrm{~mW}$ for a $5 \mathrm{~min}$ data acquisition cycle $(\mathrm{SNR}=2)$. The field measurements of all species were recorded with $1 \mathrm{~s}$ time resolution, and the precision of the measurements was calculated using the standard errors in both the online and offline points. The accuracy of the measurements was $\approx 26 \%(2 \sigma)$ and is derived from uncertainties in the calibration, which derive largely from that of the chemical actinometer (Commane et al., 2010).

\subsection{Experimental budget analysis}

An experimental budget analysis has been conducted for $\mathrm{OH}$, $\mathrm{HO}_{2}, \mathrm{RO}_{2}$ and total $\mathrm{RO}_{x}$ following the approach outlined in Tan et al. (2019) and which relies only on field-measured quantities (concentrations and photolysis rates) and published chemical kinetic data and not on any model calculated concentrations. The rates of production and destruction of each radical species are calculated using Eqs. (1)-(8) below.

$$
\begin{aligned}
\mathrm{P}_{\mathrm{OH}}= & j_{\mathrm{HONO}}[\mathrm{HONO}]+\left(2 f \times j_{\mathrm{O}^{1} \mathrm{D}}\left[\mathrm{O}_{3}\right]\right)+ \\
& \sum_{i}\left\{\varphi^{i}{ }_{\mathrm{OH}} k^{i}{ }_{1}[\text { alkene }]_{i}\left[\mathrm{O}_{3}\right]\right\}+ \\
& \left(k_{2}[\mathrm{NO}]+k_{3}\left[\mathrm{O}_{3}\right]\right)\left[\mathrm{HO}_{2}\right] \\
\mathrm{D}_{\mathrm{OH}}= & {[\mathrm{OH}] k_{\mathrm{OH}} }
\end{aligned}
$$

$$
\begin{aligned}
& \mathrm{P}_{\mathrm{HO}_{2}}=2 j_{\text {HCHO_r }}[\mathrm{HCHO}]+ \\
& \sum_{i}\left\{\varphi^{i}{ }_{\mathrm{HO}_{2}} k^{i}{ }_{1}[\text { alkene }]_{i}\left[\mathrm{O}_{3}\right]\right\}+ \\
& \mathrm{D}_{\mathrm{HO}_{2}}=\left(k_{7}[\mathrm{NO}]+k_{8}\left[\mathrm{O}_{3}\right]+k_{9}\left[\mathrm{RO}_{2}\right]+\right. \\
& \left.k_{\text {het }}+2 k_{10}\left[\mathrm{HO}_{2}\right]\right)\left[\mathrm{HO}_{2}\right] \\
& \mathrm{P}_{\mathrm{RO}_{2}}=\sum_{i}\left\{\varphi^{i}{ }_{\mathrm{RO}_{2}} k^{i}{ }_{1}[\text { alkene }]_{i}\left[\mathrm{O}_{3}\right]\right\}+ \\
& k_{\mathrm{OH}}[\mathrm{VOC}][\mathrm{OH}] \\
& \mathrm{D}_{\mathrm{RO}_{2}}=\left\{(\alpha+\beta) k_{6}[\mathrm{NO}]+\right. \\
& \left.\left(2 k_{11}\left[\mathrm{RO}_{2}\right]+k_{9}\left[\mathrm{HO}_{2}\right]\right)\right\}\left[\mathrm{RO}_{2}\right]
\end{aligned}
$$$$
\left(k_{4}[\mathrm{HCHO}]+k_{5}[\mathrm{CO}]\right)[\mathrm{OH}]+\alpha k_{6}[\mathrm{NO}]\left[\mathrm{RO}_{2}\right]
$$

$$
\begin{aligned}
\mathrm{P}_{\mathrm{RO}_{x}}= & j_{\mathrm{HONO}}[\mathrm{HONO}]+2 f \times j_{\mathrm{O}^{1} \mathrm{D}}\left[\mathrm{O}_{3}\right]+ \\
& 2 j_{\mathrm{HCHO} \_\mathrm{r}}[\mathrm{HCHO}]+ \\
& \sum_{i}\left\{\left(\varphi^{i}{ }_{\mathrm{OH}}+\varphi^{i}{ }_{\mathrm{HO}_{2}}+\varphi^{i}{ }_{\mathrm{RO}_{2}}\right) k^{i}{ }_{1}[\text { alkene }]_{i}\left[\mathrm{O}_{3}\right]\right\} \\
\mathrm{D}_{\mathrm{RO}_{x}}= & \left(k_{12}\left[\mathrm{NO}_{2}\right]+k_{13}[\mathrm{NO}]\right) \\
& {[\mathrm{OH}]+\beta k_{6}[\mathrm{NO}]\left[\mathrm{RO}_{2}\right]+} \\
& 2\left(k_{11}\left[\mathrm{RO}_{2}\right]^{2}+k_{9}\left[\mathrm{RO}_{2}\right]\left[\mathrm{HO}_{2}\right]+k_{10}\left[\mathrm{HO}_{2}\right]^{2}\right),
\end{aligned}
$$

where $j_{\mathrm{HONO}}$ and $j_{\mathrm{O}^{1} \mathrm{D}}$ are the measured photolysis rates of $\mathrm{HONO}$ and $\mathrm{O}_{3}$ (forming $\mathrm{O}^{1} \mathrm{D}$ ) respectively; $f$ is the fraction of $\mathrm{O}^{1} \mathrm{D}$ radicals that react with $\mathrm{H}_{2} \mathrm{O}$ rather than are collisionally quenched to $\mathrm{O}\left({ }^{3} \mathrm{P}\right)(f=0.1$ on average $)$; and $\varphi^{i} \mathrm{OH}$, $\varphi^{i}{ }_{\mathrm{HO}_{2}}, \varphi^{i} \mathrm{RO}_{2}$ and $k^{i}{ }_{1}$ are the yield of $\mathrm{OH}, \mathrm{HO}_{2}$ and $\mathrm{RO}_{2}$ from, and rate coefficients for, individual ozone-alkene reactions taken from the MCM3.3.1 respectively. $j_{\text {HCHO_r }}$ is the measured $\mathrm{HCHO}$ photolysis rate that yields $\mathrm{HO}_{2}$ radicals, and $k_{\text {het }}$ is the first-order loss of $\mathrm{HO}_{2}$ to the measured aerosol surface area, calculated using Eq. (9):

$k_{\text {het }}=\frac{\omega A \gamma}{4}$, 
where $\omega$ is the mean molecular speed of $\mathrm{HO}_{2}$ (equal to $43725 \mathrm{~cm} \mathrm{~s}^{-1}$ at $\left.298 \mathrm{~K}\right), \gamma$ is the aerosol uptake coefficient ( 0.2 is used here as recommended by Jacob, 2000) and $A$ is the measured aerosol surface area in $\mathrm{cm}^{2} \mathrm{~cm}^{-3} . \alpha$ is the fraction of $\mathrm{RO}_{2}$ radicals that upon reaction with $\mathrm{NO}$ propagate to $\mathrm{HO}_{2}$ rather than reform another $\mathrm{RO}_{2}$ radical; initially $\alpha=1$ has been assumed. $\beta$ is the fraction of $\mathrm{RO}_{2}$ radicals that upon reaction with $\mathrm{NO}$ form alkyl nitrates and is set to 0.05 as used by Tan et al. (2019) to represent an average alkyl nitrate yield for the various types of $\mathrm{RO}_{2}$ species likely present. All rate coefficients $\left(k_{1}-k_{13}\right)$ used are listed in Table 1 , and the concentrations of species used in the budget analysis are the concentrations that were observed during the campaign.

\subsection{MCM3.3.1 box model description}

A zero-dimensional (box) model incorporating the Master Chemical Mechanism (MCM3.3.1; Jenkin et al., 2015; http:// mcm.leeds.ac.uk/MCM/home, last access: 1 February 2021) was used to predict the radical concentrations and $\mathrm{OH}$ reactivity for comparison with the observations. The model was constrained by measurements of $\mathrm{NO}, \mathrm{NO}_{2}, \mathrm{NO}_{3}, \mathrm{O}_{3}, \mathrm{CO}$, $\mathrm{HCHO}, \mathrm{HNO}_{3}, \mathrm{HONO}$, water vapour, temperature, pressure and individual VOC species measured by DC-GC-FID (dual-channel gas chromatography with flame ionisation) and PTR-ToF-MS (proton transfer reaction time-of-flight mass spectrometry). Table 2 lists the different VOC species measured. HCHO was measured using a recently developed LIF instrument with $1 \mathrm{~s}$ time resolution and LOD of $80 \mathrm{pptv}$ (Cryer, 2016). HONO was measured by a long-path absorption photometer (LOPAP) and broadband cavity-enhanced absorption spectrophotometry (BBCEAS) and the HONO concentration as recommended in Crilley et al. (2019) are used here. Further details on all instrumentation deployed during the campaign are overviewed in Shi et al. (2019).

The model was constrained with the measured photolysis frequencies $j\left(\mathrm{O}^{1} \mathrm{D}\right), j\left(\mathrm{NO}_{2}\right)$, and $j(\mathrm{HONO})$, which were calculated from the measured wavelength-resolved actinic flux and published absorption cross sections and photodissociation quantum yields. For other species which photolyse at near-UV wavelengths $(<360 \mathrm{~nm})$, such as $\mathrm{HCHO}$ and $\mathrm{CH}_{3} \mathrm{CHO}$, the photolysis rates were calculated by scaling to the ratio of clear-sky $j\left(\mathrm{O}^{1} \mathrm{D}\right)$ to observed $j\left(\mathrm{O}^{1} \mathrm{D}\right)$ to account for clouds. For species which photolyse further into the visible, the ratio of clear-sky $j\left(\mathrm{NO}_{2}\right)$ to observed $j\left(\mathrm{NO}_{2}\right)$ was used. The variation of the clear-sky photolysis rates $(j)$ with solar zenith angle $(\chi)$ was calculated within the model using the following expression:

$j=l \cos (\chi) m \times e-n \sec (\chi)$,

with the parameters $l, m$ and $n$ optimised for each photolysis frequency (see Table 2 in Saunders et al., 2003). The model inputs were updated every $15 \mathrm{~min}$; the species that were measured more frequently were averaged to $15 \mathrm{~min}$, whilst the measurements with lower time resolution were interpolated.
To estimate how long model-generated intermediate species survive before being physically removed by processes such as deposition or ventilation, the model was left unconstrained to glyoxal, and the rate of physical loss was varied. The model was able to reproduce the observed glyoxal concentrations if a deposition velocity of $0.5 \mathrm{~cm} \mathrm{~s}^{-1}$ was used, combined with a ventilation term that increased with boundary layer depth. As the boundary layer gradually increased in the morning, the lifetime of glyoxal with respect to ventilation was $\approx 1 \mathrm{~h}$, whilst at night the lifetime gradually increased to $\approx 5 \mathrm{~h}$; this variable lifetime was applied to all modelgenerated species. As a further check on the physical loss rate imposed, the model was run unconstrained to $\mathrm{HCHO}$ using the same deposition rates and was found to reproduce the observed $\mathrm{HCHO}$ concentrations that were observed during the daytime but under-predicted the concentrations at night, potentially indicating that primary emissions of $\mathrm{HCHO}$ as well as secondary production contributed to the observed concentrations. In all the model scenarios presented in Sect. 3, the observed HCHO concentration is used. The model was run for the entirety of the campaign in overlapping $7 \mathrm{~d}$ segments. To allow all the unmeasured, model-generated intermediate species time to reach steady-state concentrations, the model was initialised with inputs from the first measurement day and spun up for $2 \mathrm{~d}$ before comparison to measurements of $\mathrm{OH}, \mathrm{HO}_{2}, \mathrm{RO}_{2}$ and $k(\mathrm{OH})$ was made. For comparison of the modelled $\mathrm{RO}_{2}$ to the observed total $\mathrm{RO}_{2}$, complex $\mathrm{RO}_{2}$ and simple $\mathrm{RO}_{2}$, the $\mathrm{RO}_{x}$ LIF instrument sensitivity towards each $\mathrm{RO}_{2}$ species in the model was determined by running a model first under the $\mathrm{RO}_{x}$ LIF reactor and then the $\mathrm{RO}_{x}$ LIF FAGE cell conditions (NO concentrations and residence times) to determine the conversion efficiency of each modelled $\mathrm{RO}_{2}$ species to $\mathrm{HO}_{2}$.

A series of model runs have been performed and are summarised in Table 3.

\section{Results and discussion}

\subsection{Overview of the chemistry and meteorology during the campaign}

As part of the AIRPRO project, gas-phase, aerosol, and meteorological observations were made at the IAP site from 21 May to 26 June 2017. Typically clear skies and elevated temperatures prevailed, with rain on just a few days. Temperatures frequently exceeded $35^{\circ} \mathrm{C}$, whilst $j\left(\mathrm{O}^{1} \mathrm{D}\right)$ peaked at just over $3 \times 10^{-5} \mathrm{~s}^{-1}$ at noon (Fig. 1). The dominant wind direction reaching the site during the summer was from the south-west, and the measured hourly mean wind speed was $3.6 \mathrm{~ms}^{-1}$ (Shi et al., 2019). Despite the close proximity of the measurement site to the heavily trafficked Jingzang highway in Beijing, mixing ratios of NO, which were elevated during the morning hours, often dropped below $500 \mathrm{pptv}$ during the afternoon. The daytime emissions of $\mathrm{NO}_{x}$ that 
Table 1. Chemical reactions that were used in the experimental budget analysis for $\mathrm{OH}, \mathrm{HO}_{2}, \mathrm{RO}_{2}$ and $\mathrm{RO}_{x}$. The rate coefficients at $298 \mathrm{~K}$ are given in column 3; temperature-dependent rate coefficients were used in the experimental budget analysis presented in Sect. 3.3.

\begin{tabular}{|c|c|c|}
\hline No. & Reaction & Rate coefficient $(298 \mathrm{~K})$ in $\mathrm{cm}^{3}$ molecule $^{-1} \mathrm{~s}^{-1}$ \\
\hline $\mathrm{R} 1$ & Alkene $+\mathrm{O}_{3} \rightarrow \mathrm{OH}, \mathrm{HO}_{2}, \mathrm{RO}_{2}+$ products & $\begin{array}{l}\text { Specific rate coefficients and radical yields for each } \\
\text { alkene, taken from the MCM3.3.1 (Jenkin et al., 2015) }\end{array}$ \\
\hline R2 & $\mathrm{NO}+\mathrm{HO}_{2} \rightarrow \mathrm{OH}+\mathrm{NO}$ & $8.5 \times 10^{-12}$ \\
\hline R3 & $\mathrm{O}_{3}+\mathrm{HO}_{2} \rightarrow \mathrm{OH}+2 \mathrm{O}_{2}$ & $2.0 \times 10^{-15}$ \\
\hline R4 & $\mathrm{HCHO}+\mathrm{OH}+\mathrm{O}_{2} \rightarrow \mathrm{CO}+\mathrm{HO}_{2}+\mathrm{H}_{2} \mathrm{O}$ & $8.4 \times 10^{-12}$ \\
\hline R5 & $\mathrm{CO}+\mathrm{OH}+\mathrm{O}_{2} \rightarrow \mathrm{HO}_{2}+\mathrm{CO}_{2}$ & $2.3 \times 10^{-13}$ \\
\hline R6 & $\mathrm{RO}_{2}+\mathrm{NO} \rightarrow \mathrm{RO}+\mathrm{NO}_{2}$ & $8.7 \times 10^{-12}$ \\
\hline R7 & $\mathrm{HO}_{2}+\mathrm{NO} \rightarrow \mathrm{OH}+\mathrm{NO}_{2}$ & $8.5 \times 10^{-12}$ \\
\hline R8 & $\mathrm{HO}_{2}+\mathrm{O}_{3} \rightarrow \mathrm{OH}+2 \mathrm{O}_{2}$ & $2.0 \times 10^{-15}$ \\
\hline R9 & $\mathrm{HO}_{2}+\mathrm{RO}_{2} \rightarrow \mathrm{ROOH}+\mathrm{O}_{2}$ & $2.3 \times 10^{-11}$ \\
\hline \multirow[t]{2}{*}{ R10 } & $\mathrm{HO}_{2}+\mathrm{HO}_{2} \rightarrow \mathrm{H}_{2} \mathrm{O}_{2}+\mathrm{O}_{2}$ & $1.7 \times 10^{-12}$ \\
\hline & $\mathrm{HO}_{2}+\mathrm{HO}_{2}+\mathrm{H}_{2} \mathrm{O} \rightarrow \mathrm{H}_{2} \mathrm{O}_{2}+\mathrm{H}_{2} \mathrm{O}+\mathrm{O}_{2}$ & $6.4 \times 10^{-30}$ \\
\hline R11 & $\mathrm{RO}_{2}+\mathrm{RO}_{2} \rightarrow$ products & $3.5 \times 10^{-13}$ \\
\hline R12 & $\mathrm{OH}+\mathrm{NO}_{2} \rightarrow \mathrm{HNO}_{3}$ & $1.1 \times 10^{-11}$ \\
\hline R13 & $\mathrm{OH}+\mathrm{NO} \rightarrow \mathrm{HONO}$ & $7.5 \times 10^{-12}$ \\
\hline
\end{tabular}

Table 2. The species measured by DC-GC-FID and PTR-ToF-MS that have been used as constraints in the model.

\begin{tabular}{|c|c|c|}
\hline Instrument & Species & Reference \\
\hline DC-GC-FID & $\begin{array}{l}\mathrm{CH}_{4}, \mathrm{C}_{2} \mathrm{H}_{6}, \mathrm{C}_{2} \mathrm{H}_{4}, \mathrm{C}_{3} \mathrm{H}_{8}, \mathrm{C}_{3} \mathrm{H}_{6} \text {, isobutane, butane, } \mathrm{C}_{2} \mathrm{H}_{2} \text {, trans-but-2-ene, } \\
\text { but-1-ene, isobutene, cis-but-2-ene, 2-methylbutane, pentane, 1,3-butadiene, } \\
\text { trans-2-pentene, cis-2-pentene, 2-methylpetane, 3-methylpetane, hexane, iso- } \\
\text { prene, heptane, benzene, toluene, o- } x y l e n e, \mathrm{CH}_{3} \mathrm{OH}, \mathrm{CH}_{3} \mathrm{OCH}_{3} \text {, ethylbenzene, } \\
\mathrm{CH}_{3} \mathrm{CHO}, \mathrm{C}_{2} \mathrm{H}_{5} \mathrm{OH}\end{array}$ & Hopkins et al. (2011) \\
\hline PTR-ToF-MS & $\begin{array}{l}\alpha \text {-pinene, limonene, isopropylbenzene, propylbenzene, xylene, trimethylben- } \\
\text { zene }\end{array}$ & Huang et al. (2016) \\
\hline
\end{tabular}

were recorded during the project displayed a rapid increase at 05:00 and then remained reasonably constant throughout the day, with a mean flux value of $4.6 \mathrm{mg} \mathrm{m}^{-2} \mathrm{~h}^{-1}$, before dropping again at 17:00 (Squires et al., 2020). The rapid decrease in NO into the afternoon, therefore, was not driven by a change in emissions, but rather instead by the increasing boundary layer depth and also by the chemistry, as elevated levels of ozone observed in the afternoon effectively titrated $\mathrm{NO}$ to $\mathrm{NO}_{2}$ (Newland et al., 2020). Isoprene mixing ratios also peaked in the afternoon, often reaching a few parts per billion (ppbv), indicative of a biogenic source. The variation in $\mathrm{NO}_{x}$ and VOC concentrations experienced at the site provides an opportunity to assess the skill of the MCM to capture the complex chemistry occurring over an extremely wide range of chemical regimes that encompasses both typical ur- ban conditions (high $\mathrm{NO}_{x}$ ) as well as chemical conditions more akin to forested environments (low NO, high biogenic VOC (BVOC)). From 9 to 12 June, NO levels were elevated throughout the day, suggesting a local source, whilst from 17 June to the end of the measurement period, NO concentrations dropped, and so, as well as the strong diurnal trend observed in the NO concentration, these periods provide further opportunity to test the model's ability to predict radical concentrations as a function of NO by removing concomitant variables such as changing boundary layer depth and sunrise which occurred in unison with the morning increase in NO concentration. 
Table 3. Different model scenarios that are discussed in Sect. 3.

\begin{tabular}{|c|c|}
\hline Model name & Description \\
\hline Base model & As described in Sect. 2.4 \\
\hline Base model-SA & $\begin{array}{l}\text { The base model with the inclusion of a first-order loss process of } \mathrm{HO}_{2} \text { to } \\
\text { aerosols calculated using Eq. (9) with an uptake coefficient, } \gamma=0.2\end{array}$ \\
\hline Base model-Cl & $\begin{array}{l}\text { The base model with the inclusion of } \mathrm{Cl} \text { atom chemistry, taken from Xue et al. } \\
\text { (2015) }\end{array}$ \\
\hline Missing $k(\mathrm{OH})\left(\mathrm{OH}\right.$ to $\left.\mathrm{CH}_{3} \mathrm{O}_{2}\right)$ & $\begin{array}{l}\text { The base model with an additional reaction converting } \mathrm{OH} \text { to } \mathrm{CH}_{3} \mathrm{O}_{2} \text { at a rate } \\
\text { equal to the missing reactivity }\end{array}$ \\
\hline Missing $k(\mathrm{OH})\left(\mathrm{OH}\right.$ to $\left.\mathrm{HOCH}_{2} \mathrm{CH}_{2} \mathrm{O}_{2}\right)$ & $\begin{array}{l}\text { The base model with an additional reaction converting } \mathrm{OH} \text { to } \mathrm{HOCH}_{2} \mathrm{CH}_{2} \mathrm{O}_{2} \\
\text { at a rate equal to the missing reactivity }\end{array}$ \\
\hline Missing $k(\mathrm{OH})\left(\mathrm{OH}\right.$ to $\left.\mathrm{CH}_{3} \mathrm{C}(\mathrm{O}) \mathrm{O}_{2}\right)$ & $\begin{array}{l}\text { The base model with an additional reaction converting } \mathrm{OH} \text { to } \mathrm{CH}_{3} \mathrm{C}(\mathrm{O}) \mathrm{O}_{2} \text { at a } \\
\text { rate equal to the missing reactivity }\end{array}$ \\
\hline Missing $k(\mathrm{OH})(\mathrm{OH} \text { to } \mathrm{C} 96 \mathrm{O} 2)^{1}$ & $\begin{array}{l}\text { The base model with an additional reaction converting } \mathrm{OH} \text { to } \\
\mathrm{C} 96 \mathrm{O} 2 \text { (which is an } \alpha \text {-pinene-derived } \mathrm{RO}_{2} \text { species) at a rate } \\
\text { equal to the missing reactivity }\end{array}$ \\
\hline
\end{tabular}
1 Note that $\mathrm{C} 96 \mathrm{O} 2$ is an $\alpha$-pinene-derived $\mathrm{RO}_{2}$ that forms during the ozone-initiated oxidation of $\alpha$-pinene. The additional production of $\mathrm{C} 96 \mathrm{O} 2$ peroxy radicals
in this model scenario was used to investigate the impact of an $\mathrm{RO}$ isomerisation mechanism on the modelled radical concentrations.

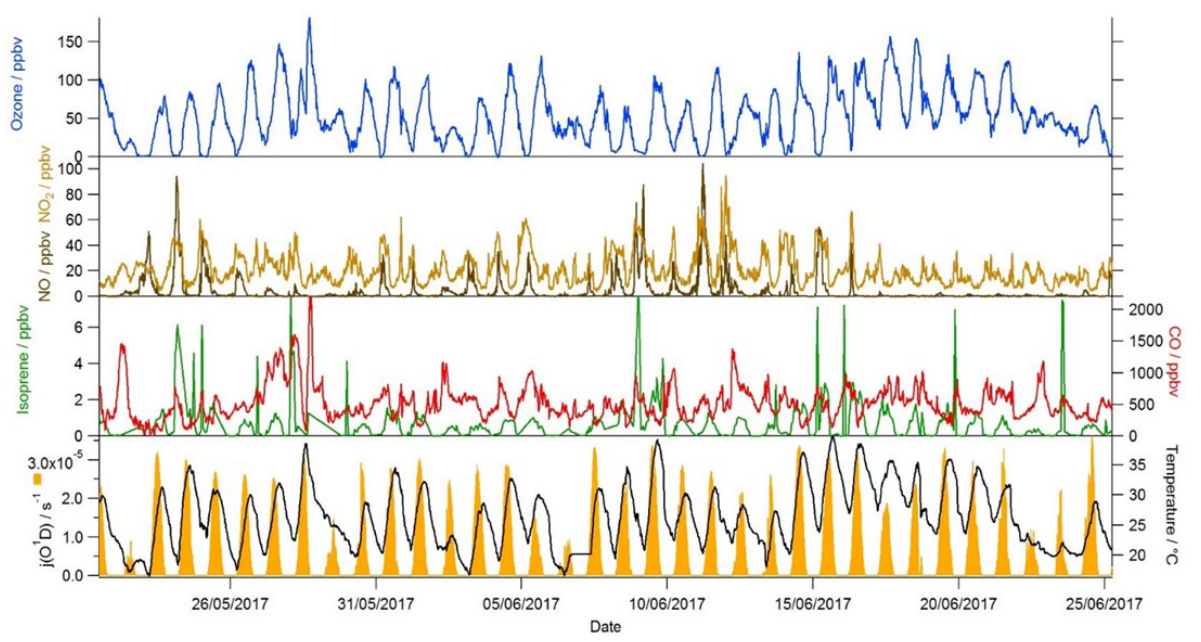

Figure 1. Time series of ozone, $\mathrm{NO}, \mathrm{NO}_{2}$ isoprene, $\mathrm{CO}, j\left(\mathrm{O}^{1} \mathrm{D}\right)$ and temperature during the campaign

\subsection{Radical concentrations and $\mathrm{OH}$ reactivity}

The concentrations of $\mathrm{RO}_{x}\left(\mathrm{OH}+\mathrm{HO}_{2}+\mathrm{RO}_{2}\right)$ radicals were high during the campaign (Fig. 2), with $\mathrm{OH}$ concentrations frequently exceeding $1 \times 10^{7}$ molecule $\mathrm{cm}^{-3}$ and reaching up to $2.8 \times 10^{7}$ molecule $\mathrm{cm}^{-3}$ on 30 May. These $\mathrm{OH}$ levels are amongst the highest measured in an urban environment (Lu et al., 2019) and are comparable to the $\mathrm{OH}$ concentrations observed in the Pearl River Delta downwind of the southern Chinese megacity of Guangzhou, where $\mathrm{OH}$ concentrations reached $2.6 \times 10^{7}$ molecule $\mathrm{cm}^{-3}$ (Lu et al., 2012). $\mathrm{HO}_{2}$ concentrations peaked at $1 \times 10^{9}$ molecule $\mathrm{cm}^{-3}$ on 9 June, whilst the highest concentrations of total $\mathrm{RO}_{2}$ were observed during the latter half of the campaign, peaking at $5.5 \times 10^{9}$ molecule $\mathrm{cm}^{-3}$ on the afternoon of 15 June. $\mathrm{RO}_{2}$ measurements, alongside $\mathrm{OH}$ and $\mathrm{HO}_{2}$, were, until recently, relatively rare. $\mathrm{OH}$ and $\mathrm{RO}_{x}$ were measured during the MEGAPOLI project in Paris (Michoud et al., 2012), where the average daytime maximum concentrations of $\mathrm{RO}_{x}$ were $1.2 \times 10^{8}$ molecule $\mathrm{cm}^{-3}$, which is over an order of magnitude lower than the levels observed in Beijing. Since the development of the $\mathrm{RO}_{x}$ LIF technique (Fuchs et al., 2008), $\mathrm{RO}_{2}$ observations are now reported by the Leeds, Juelich and PKU FAGE groups. $\mathrm{RO}_{2}$ concentrations observed in London in the summer reached up to $5.5 \times$ $10^{8}$ molecule $\mathrm{cm}^{-3}$ in air masses that had previously passed 
over central London (Whalley et al., 2018). In Wangdu, a town situated on the North China Plain, $170 \mathrm{~km}$ north-east of Beijing, summertime $\mathrm{RO}_{2}$ concentrations reached up to $1.5 \times 10^{9}$ molecule $\mathrm{cm}^{-3}$ (Tan et al., 2017), which, although lower than observed in central Beijing, are much higher than observed in the summertime in European cities, suggesting that there may be significant differences in the urban photochemistry occurring in China and Europe.

As well as the elevated daytime radical concentrations, concentrations of $\mathrm{OH}, \mathrm{HO}_{2}$ and $\mathrm{RO}_{2}$ remained elevated above the instrumental LOD on most nights. The high nighttime $\mathrm{OH}$ concentrations (ranging from the LOD up to $2 \times 10^{6}$ molecule $\mathrm{cm}^{-3}$ ) are comparable to the levels of $\mathrm{OH} \mathrm{ob}-$ served at night in Yufa (a suburb of Beijing) and downwind of Guangzhou, where night-time $\mathrm{OH}$ concentrations ranged from $0.5-3 \times 10^{6}$ molecule $\mathrm{cm}^{-3}$ ( $\mathrm{Lu}$ et al., 2014). The observations of $\mathrm{OH}$ from the earlier Chinese campaigns could be reconciled by a model if an additional $\mathrm{RO}_{x}$ production process was included which recycled $\mathrm{RO}_{2}$ to $\mathrm{OH}$ via $\mathrm{HO}_{2}$. A weak positive correlation is observed between night-time $\mathrm{OH}$ and $\mathrm{RO}_{2}$ during AIRPRO, and the secondary peak in $\mathrm{RO}_{2}$ occurred when $\mathrm{NO}_{3}$ was observed to increase rapidly at $\approx 19: 30$, suggesting that nitrate chemistry was one source of radicals in the evening. Alkyl nitrates, formed from isoprene $+\mathrm{NO}_{3}$, were also enhanced at these times at this site (Reeves et al., 2019).

The $\mathrm{OH}$ reactivity, typical of urban environments, displayed an inverse relationship with boundary layer height and was highest during the nights when emissions were compressed into a lower boundary layer depth of $\approx 150 \mathrm{~m}$. An average maximum of $k(\mathrm{OH}) \approx 37 \mathrm{~s}^{-1}$ was observed at 06:00, with $\mathrm{OH}$ reactivity reaching $89 \mathrm{~s}^{-1}$ on 15 June at 03:00. During the daytime, the $\mathrm{OH}$ reactivity dropped to a minimum of $\approx 22 \mathrm{~s}^{-1}$ on average at $\approx 15: 00$ when the boundary layer had increased to $\approx 1500 \mathrm{~m}$. The magnitude of $\mathrm{OH}$ reactivity observed during AIRPRO is comparable to the $\mathrm{OH}$ reactivity observed at other urban sites in China in the summer (Lou et al., 2010; Fuchs et al., 2017) and also in Tokyo during the summer (Sadanaga et al., 2004; Chatani et al., 2009). In London, $\mathrm{OH}$ reactivity was approximately $\approx 7-10 \mathrm{~s}^{-1}$ lower than in central Beijing, with $\approx 15 \mathrm{~s}^{-1}$ observed during the day on average and an average maximum of $\approx 27 \mathrm{~s}^{-1}$ at 06:00 (Whalley et al., 2016). Lower OH reactivities are also reported from US urban sites in New York and Texas (Ren et al., 2003; Mao et al., 2010).

\subsection{Experimental radical budget analysis}

Owing to the relatively short lifetime of radicals, it can be assumed that their production rates and destruction rates are balanced. A comparison of the rates of production and destruction for each radical species can be used to help identify if all radical sources and sinks are accounted for and if the rates of propagation between radical species are fully understood. In London, the ratio of the $\mathrm{OH}$ production rate
(Eq. 1) to $\mathrm{OH}$ destruction rate (Eq. 2) was generally close to 1 throughout the campaign, demonstrating consistency between the $\mathrm{OH}, \mathrm{HO}_{2}, k(\mathrm{OH}), \mathrm{HONO}$ and $\mathrm{NO}$ observations (Whalley et al., 2018). However, under low NO conditions $(<0.5 \mathrm{ppbv})$, the rate of $\mathrm{OH}$ destruction exceeded the calculated production rate, indicating that Eq. 1 was missing a source term under these regimes (Whalley et al., 2018). A steady-state analysis of $\mathrm{HO}_{2}$ conducted for the London project, which balanced the $\mathrm{HO}_{2}$ production terms (Eq. 3) with the first- and second-order loss terms (Eq. 4), highlighted that closure between the production and destruction terms could only be reconciled if the rate of propagation of the observed $\mathrm{RO}_{2}$ radicals to $\mathrm{HO}_{2}$ was decreased substantially to just $15 \%$, demonstrating that the mechanism by which $\mathrm{RO}_{2}$ radicals propagate to other radical species may not be well understood (Whalley et al., 2018). As set out by Tan et al. (2019), analogous budget analyses can be performed for $\mathrm{RO}_{2}$ species (Eqs. 5 and 6) and for the entire $\mathrm{RO}_{x}$ budget (Eqs. 7 and 8). Tan et al. (2019) found that the production and destruction terms for $\mathrm{RO}_{2}$ were balanced in the mornings in the PRD, when the measured $\mathrm{OH}$ reactivity was used to calculate the rate of $\mathrm{RO}_{2}$ production from $\mathrm{VOC}+\mathrm{OH}$ reactions, but during the afternoon a missing $\mathrm{RO}_{2}$ sink (2-5 ppbv h ${ }^{-1}$ ) was evident. In the PRD study (Tan et al., 2019), the $\mathrm{OH}$ destruction rate exceeded the production rate by $4-6 \mathrm{ppbvh}^{-1}$ in the afternoon, but, in contrast to London (Whalley et al., 2018), the $\mathrm{HO}_{2}$ budget was closed throughout the whole day. The total rates of $\mathrm{RO}_{x}$ production and destruction were in good agreement in the PRD (Tan et al., 2019).

A comparison of the campaign median production and destruction rates for $\mathrm{RO}_{x}, \mathrm{OH}, \mathrm{HO}_{2}$ and $\mathrm{RO}_{2}$ during AIRPRO is presented in Fig. 3. The total rates of $\mathrm{RO}_{x}$ production and destruction are in good agreement throughout the day from $\approx 10: 00$. A night-time source of radicals of just under $1 \mathrm{ppbvh}^{-1}$ is missing from the budget analysis, likely reflecting missing production from $\mathrm{NO}_{3}+\mathrm{VOC}$ reactions (nighttime radical production is considered further in Sect. 3.5). From 06:00 to 10:00, the $\mathrm{RO}_{x}$ destruction exceeds the production by up to $4 \mathrm{ppbvh}^{-1}$, indicating a substantial, $\approx 50 \%$, missing primary $\mathrm{RO}_{x}$ source at this time. Previous work has suggested that $\mathrm{Cl}$-initiated VOC oxidation may be an important source of $\mathrm{RO}_{2}$ radicals in urban regions (Riedel et al., 2014; Bannan et al., 2015; Tan et al., 2017) but has not been included in the $\mathrm{RO}_{x}$ or $\mathrm{RO}_{2}$ production rate calculations here. Nitryl chloride was measured for part of the AIRPRO campaign, and the impact of this on the modelled $\mathrm{RO}_{2}$ concentration is investigated in Sect. 3.4. The total $\mathrm{RO}_{x}$ production and destruction rate is of the order of $6 \mathrm{ppbv} \mathrm{h}^{-1}$ at noon, which is slightly faster than in the PRD, where a median peak total radical production rate of $\approx 4 \mathrm{ppbvh}^{-1}$ was calculated. The median $\mathrm{OH}$ destruction rate is $\approx 30 \mathrm{ppbvh}^{-1}$ at noon and is roughly twice as fast the production rate at this time, highlighting a large missing source of $\mathrm{OH}$ radicals in the budget $\left(\approx 15 \mathrm{ppbvh}^{-1}\right)$. Although a missing $\mathrm{OH}$ source was also re- 


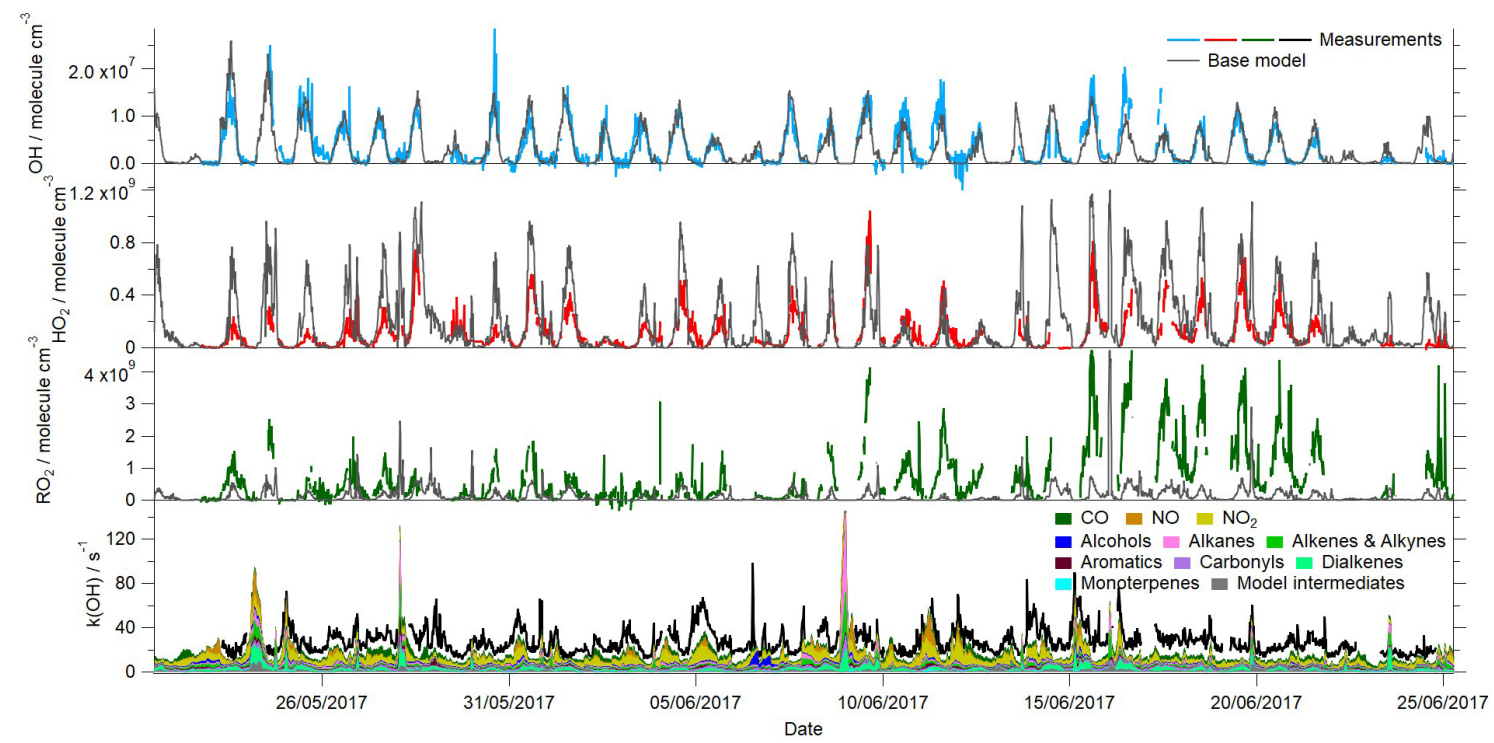

Figure 2. Time series of the measured and modelled $\mathrm{OH}, \mathrm{HO}_{2}$, total $\mathrm{RO}_{2}$ and $\mathrm{OH}$ reactivity during the campaign.
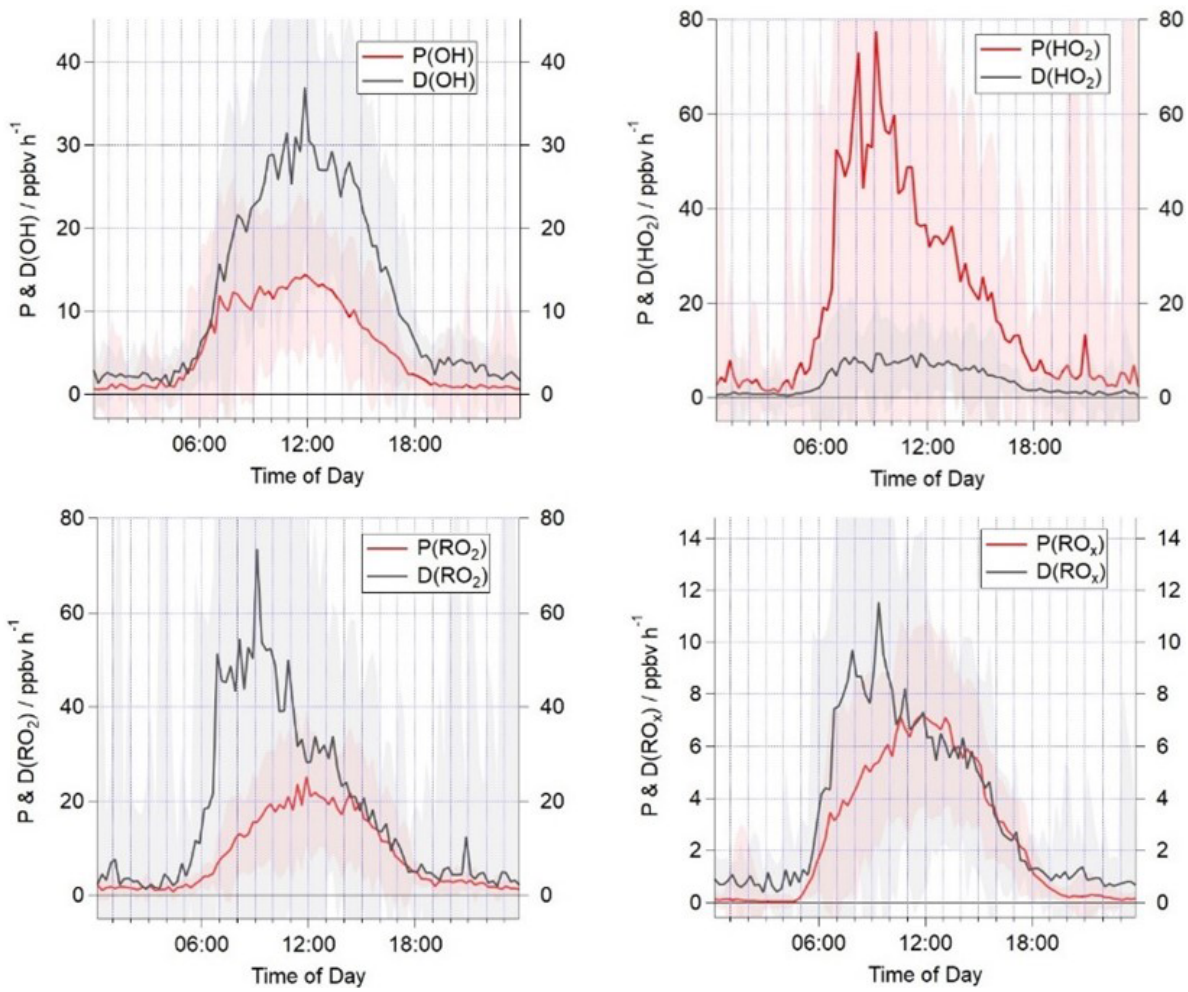

Figure 3. Campaign median production and destruction rates for $\mathrm{OH}, \mathrm{HO}_{2}$, total $\mathrm{RO}_{2}$ and $\mathrm{RO}_{x}$. The shaded areas represent the $1 \sigma$ standard deviation of the data, representing the variability from day to day.

ported in the PRD (Tan et al., 2019), the missing production rate is $\approx 3$ times faster during AIRPRO. The known $\mathrm{OH}$ production rate during AIRPRO is dominated by the reaction of $\mathrm{HO}_{2}$ with $\mathrm{NO}$ (contributing $\approx 60 \%$ during the day to $\mathrm{P}(\mathrm{OH})$ in Eq. 1). The median peak $\mathrm{HO}_{2}$ production of $\approx 60 \mathrm{ppbvh}^{-1}$ is observed in the morning hours and greatly exceeded the known rate of $\mathrm{HO}_{2}$ destruction by $\approx 50 \mathrm{ppbvh}^{-1}$. $\mathrm{HO}_{2}$ production is driven by the reaction of $\mathrm{RO}_{2}$ with $\mathrm{NO}$, which accounts for $88 \%$ of the total. The reaction of $\mathrm{OH}$ with $\mathrm{CO}$ and $\mathrm{HCHO}$ accounts for a further $9 \%$. The total $\mathrm{HO}_{2}$ production 
rate is approximately 4 times faster than that calculated for the PRD (Tan et al., 2019). The total rate of $\mathrm{RO}_{2}$ destruction mirrors the $\mathrm{HO}_{2}$ production, in that it is dominated by the reaction of $\mathrm{RO}_{2}$ radicals with NO. From sunrise to $14: 00$, the rate of $\mathrm{RO}_{2}$ destruction is faster than $\mathrm{RO}_{2}$ production by up to $50 \mathrm{ppbvh}^{-1}$. After 14:00, the rates of $\mathrm{RO}_{2}$ production and destruction are in good agreement. This trend contrasts with the budget analysis presented from PRD (Tan et al., 2019), which highlighted a possible missing $\mathrm{RO}_{2}$ sink during the afternoon hours and budget closure in the morning hours.

Binning the ratio of $\mathrm{P}(\mathrm{OH})$ to $\mathrm{D}(\mathrm{OH}), \mathrm{P}\left(\mathrm{HO}_{2}\right)$ to $\mathrm{D}\left(\mathrm{HO}_{2}\right)$ and $\mathrm{P}\left(\mathrm{RO}_{2}\right)$ to $\mathrm{D}\left(\mathrm{RO}_{2}\right)$ against the $\mathrm{NO}$ mixing ratio (Fig. 4) reveals that the $\mathrm{RO}_{2}$ budget is in good agreement at the lowest NO mixing ratios, but as NO mixing ratios increase the destruction of $\mathrm{RO}_{2}$ becomes faster than the production of $\mathrm{RO}_{2}$ by up to a factor of 10 at the highest $\mathrm{NO}$ bin. The trends in the $\mathrm{RO}_{2}$ and $\mathrm{HO}_{2}$ ratios are similar in the morning hours, albeit in opposite directions, and suggest that rather than there being a missing primary source of $\mathrm{RO}_{2}$ and missing sink for $\mathrm{HO}_{2}$ that happen to balance, instead, as found in London (Whalley et al., 2018), the net propagation rate of $\mathrm{RO}_{2}$ to $\mathrm{HO}_{2}$ may be substantially slower than the rate that has currently been used in this analysis. In London (Whalley et al., 2018), the modelled rate of production analysis revealed that only $\approx 50 \%$ of the total $\mathrm{RO}_{2}$ species propagated to $\mathrm{HO}_{2}$ following reaction with $\mathrm{NO}$, as a significant fraction of the alkoxy radicals formed (such as those generated during the oxidation of monoterpenes and long-chain alkanes) preferentially isomerised and reformed a more oxidised $\mathrm{RO}_{2}$ species in the presence of $\mathrm{O}_{2}$ instead. In the radical flux analysis using the MCM3.2 for London (Whalley et al., 2018), the propagation of alkyl- and acyl- $\mathrm{RO}_{2}$ species were combined, and so the interconversion of acyl- $\mathrm{RO}_{2}$ radicals (from the OH-initiated oxidation of aldehydic VOCs, photolysis of ketones and decomposition of PAN species) to alkyl- $\mathrm{RO}_{2}$ radicals following reaction with $\mathrm{NO}$ was not explicitly shown, but this interconversion of one $\mathrm{RO}_{2}$ species to another would serve to reduce the fraction of $\mathrm{RO}_{2}$ radicals that propagate to $\mathrm{HO}_{2}$ further. Thus far for AIRPRO, the experimental budget analysis has assumed that $95 \%$ of the measured $\mathrm{RO}_{2}$ species, upon reaction with $\mathrm{NO}$, produce $\mathrm{HO}_{2}$. If, however, a large fraction of the total $\mathrm{RO}_{2}$ measured derive from long-chain alkanes, monoterpenes or acyl- $\mathrm{RO}_{2}$ species, the budget analysis will overestimate $\mathrm{HO}_{2}$ production and also the net $\mathrm{RO}_{2}$ destruction, as the reaction of these peroxy radicals with $\mathrm{NO}$ effectively converts one $\mathrm{RO}_{2}$ species to another $\mathrm{RO}_{2}$ species, and so the reaction with $\mathrm{NO}$ will be neutral in terms of $\mathrm{RO}_{2}$ production and destruction. Taking $\alpha=0.1$ leads to a good agreement between the production and destruction rates of $\mathrm{HO}_{2}$ over the whole day and the observed range of NO. The production and destruction rates of $\mathrm{RO}_{2}$ agree under high $\mathrm{NO}$ conditions, but at $\mathrm{NO}$ mixing ratios $<5 \mathrm{ppbv}$ the production of $\mathrm{RO}_{2}$ exceeds the destruction, highlighting (if this $\alpha$ value is correct) that there is a missing $\mathrm{RO}_{2}$ sink at the lower $\mathrm{NO}$ concentrations. Tan et al. (2019) also report a missing $\mathrm{RO}_{2}$
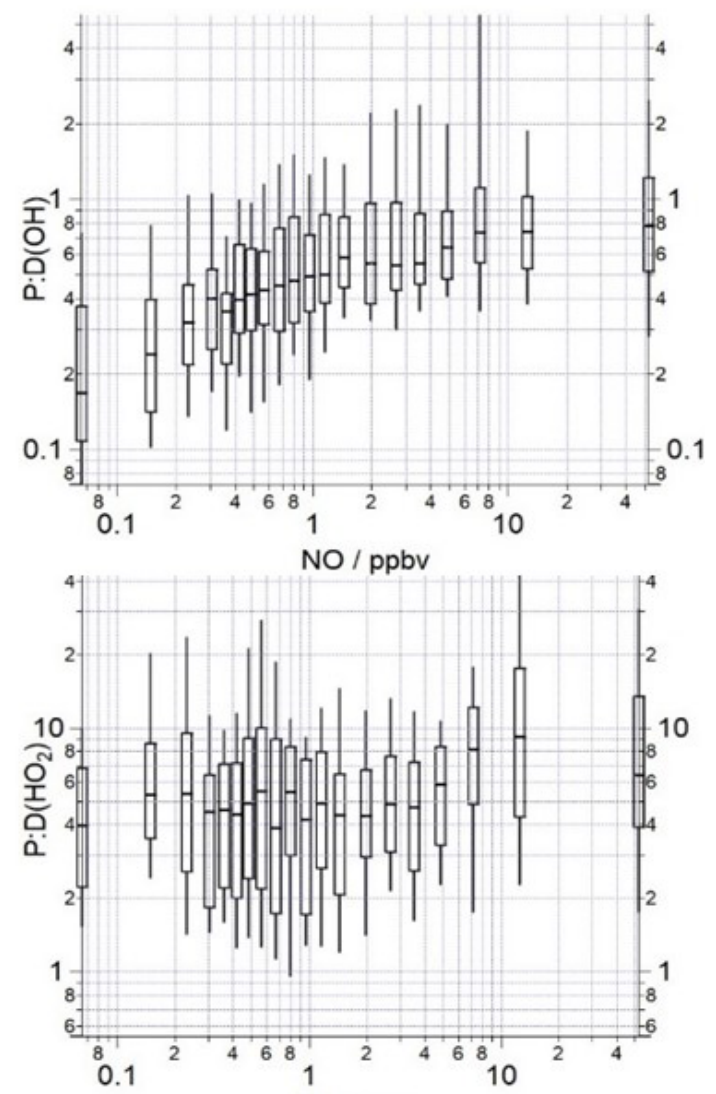

$\mathrm{NO} / \mathrm{ppbv}$

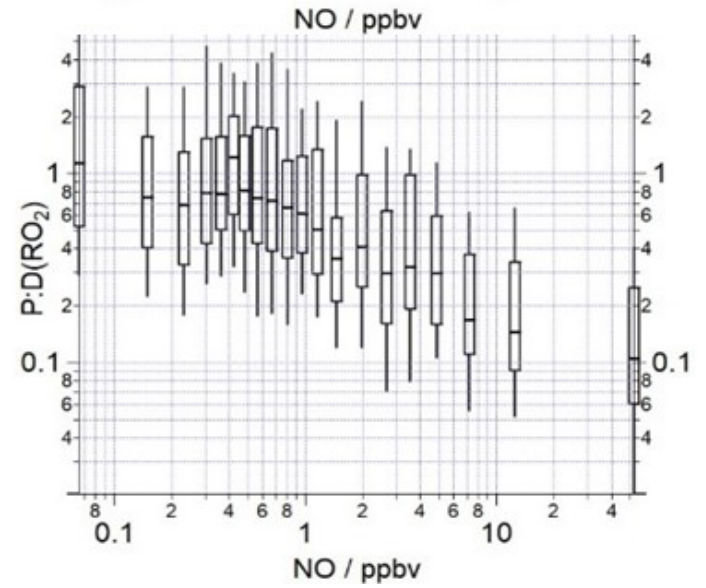

Figure 4. The median ratio of the $\mathrm{OH}, \mathrm{HO}_{2}$ and total $\mathrm{RO}_{2}$ production rates to destruction rates binned over the NO mixing ratio range encountered during the campaign on a logarithmic scale. The box and whiskers represent the 25 th and 75 th and the 5th and 95th confidence intervals. The number of data points in each of the NO bins is $\approx 80$.

sink under low NO conditions during PRD and suggested that autoxidation of $\mathrm{RO}_{2}$ species could account for this missing sink and may also possibly act as the missing source of $\mathrm{OH}$ identified under the low NO conditions. An additional firstorder reaction that converts $\mathrm{RO}_{2}$ to $\mathrm{OH}$ at a rate of $0.1 \mathrm{~s}^{-1}$ brings the $\mathrm{P}: \mathrm{D}(\mathrm{OH})$ and $\mathrm{P}: \mathrm{D}\left(\mathrm{RO}_{2}\right)$ ratios close to 1 at all 
NO mixing ratios $>0.3 \mathrm{ppbv}$, but at low $\mathrm{NO}$ mixing ratios $(0.1-0.3$ ppbv range) an even slower rate of conversion is required, highlighting, as one might expect, that the overall rate of $\mathrm{RO}_{2}$ isomerisation is variable and likely depends on the specific $\mathrm{RO}_{2}$ species present at a particular time or location. In the PRD study (Tan et al., 2019), the $\mathrm{HO}_{2}$ budget was closed when $\alpha=0.95$ was used, suggesting that acyl peroxy radicals and those derived from long-chain alkanes and monoterpenes only made up a very small fraction of the total $\mathrm{RO}_{2}$ concentration.

Although revealing, this type of experimental budget analysis coupled with the radical observations is unable to differentiate between different $\mathrm{RO}_{2}$ types, and so assumptions have to be made on the fraction of the total $\mathrm{RO}_{2}$ that propagate to $\mathrm{HO}_{2}$. In the following section, a box model constrained to the latest MCM scheme (MCM3.3.1) is used to predict the radical concentrations. The MCM is a nearexplicit model and, as such, treats the production, propagation and destruction of each $\mathrm{RO}_{2}$ species present discretely and so can provide an insight into the rate at which different $\mathrm{RO}_{2}$ species convert to $\mathrm{HO}_{2}$ or to other $\mathrm{RO}_{2}$ species (or, indeed to $\mathrm{OH}$ ) and the impact this propagation has on NO to $\mathrm{NO}_{2}$ conversion and, hence, $\mathrm{O}_{3}$ production.

\subsection{MCM modelled radical predictions and comparison with observations}

The time series of the model-predicted radical concentrations and a breakdown of the modelled $\mathrm{OH}$ reactivity from the base MCM model are overlaid with the observations in Fig. 2. The average diurnal profiles of the measured and modelled radical and $k(\mathrm{OH})$ profiles are also provided in Fig. 5. In contrast to the experimental budget analysis, the model-predicted $\mathrm{OH}$ is in excellent agreement with the observed $\mathrm{OH}$ throughout the campaign. This same model overestimates $\mathrm{HO}_{2}$, however, particularly during the daytime but also during the evening when a small secondary peak in $\mathrm{HO}_{2}$ is predicted but not observed. An exception to this trend occurs between 9-12 June when elevated levels of NO were measured at the site during the day, and on these days, the agreement between the observed $\mathrm{HO}_{2}$ and the model is better. The over-prediction of $\mathrm{HO}_{2}$ primarily occurs under the lower NO conditions that were typically observed during the afternoon hours; the skill of the model to predict the radical concentrations as a function of $\mathrm{NO}$ is discussed further below. The model underestimates total $\mathrm{RO}_{2}$ throughout the measurement period, although the level of disagreement (in terms of absolute concentration) is most severe (15-22 June) when NO concentrations were at their lowest. During this period, the average NO mixing ratio was $\approx 0.4 \mathrm{ppbv}$ during the afternoon hours, whilst the average $\mathrm{NO}$ mixing ratio for the entirety of the campaign was $\approx 0.75 \mathrm{ppbv}$ during the afternoons (Fig. S1 in the Supplement). The average peak NO mixing ratio observed in the morning (1-22 June) was just over 6 ppbv, whilst the average peak NO mixing ratio for the entirety of the campaign was close to $16 \mathrm{ppbv}$. During this period, the observed $\mathrm{RO}_{2}$ concentrations were most elevated relative to other times during the campaign; however, the model does not predict a similar increase in $\mathrm{RO}_{2}$ concentrations during this period relative to other times in the campaign. $\mathrm{OH}$ reactivity is underestimated by the model, on average by $\approx 10 \mathrm{~s}^{-1}$. However, between $15-22$ June the average missing $\mathrm{OH}$ reactivity increases to $\approx 13 \mathrm{~s}^{-1}$. The model underestimation of $\mathrm{OH}$ reactivity may, in part, contribute to the model underestimation of $\mathrm{RO}_{2}$ as the model is evidently underestimating the rate of $\mathrm{OH}+\mathrm{VOC}$ reactions which form $\mathrm{RO}_{2}$. Including an additional reaction between $\mathrm{OH}$ and $\mathrm{VOC}$ to account for the missing reactivity in the model and the impact this has on the modelled radical concentrations is investigated in Sect. 3.6. Although the model is able to capture the observed $\mathrm{OH}$ concentrations reasonably well, the model's failure to reproduce the observed $\mathrm{HO}_{2}$ and $\mathrm{RO}_{2}$ (and in the base model, the $\mathrm{OH}$ reactivity) indicates the model is either missing or misrepresenting some key reactions. Furthermore, the discrepancy between the model-predicted $\mathrm{OH}$ and $\mathrm{OH}$ budget analysis which highlighted a missing $\mathrm{OH}$ source, suggests that the over-prediction of $\mathrm{HO}_{2}$ is masking a missing $\mathrm{OH}$ source in the MCM model.

Qualitatively, the model overestimation of $\mathrm{HO}_{2}$ and underestimation of $\mathrm{RO}_{2}$ is consistent with the budget analysis, which identified a missing $\mathrm{RO}_{2}$ production term and missing $\mathrm{HO}_{2}$ destruction term which could be reconciled, in part, by slowing the rate at which $\mathrm{RO}_{2}$ propagates to $\mathrm{HO}_{2}$. However, when the $\mathrm{HO}_{2}$ measured to modelled ratio is binned against NO, differences between the model and budget analyses become apparent (Fig. 6). The model over-predicts the observed $\mathrm{HO}_{2}$ concentrations at the lowest $\mathrm{NO}$ mixing ratios experienced (0.1-1 ppbv); this over-prediction can be reconciled (under the very lowest NO conditions, $<0.3 \mathrm{ppbv}$ ) when a loss of $\mathrm{HO}_{2}$ to aerosols (calculated using Eq. 9, with an uptake coefficient of 0.2) is included in the model. This demonstrates that a reduction in aerosol surface area has the potential to enhance $\mathrm{HO}_{2}$ concentrations and thereby increase photochemical ozone formation but only under very low NO conditions. As there was little to no change in the modelled $\mathrm{HO}_{2}$ concentration upon inclusion of an heterogeneous loss term under the higher NO conditions, efforts to reduce anthropogenic PM when NO is present (which is highly likely to be the case) would not be expected to lead to an increase in $\mathrm{HO}_{2}$ and, in turn, $\mathrm{O}_{3}$, as was suggested from earlier modelling studies ( $\mathrm{Li}$ et al., 2019). Between $1-5$ ppbv NO, the model is able to reproduce the observed $\mathrm{HO}_{2}$ well (between 9-12 June, the daytime NO concentrations fell within this intermediate NO range, hence the good agreement between the model and observations on these days). In contrast with the budget analysis, the model under-predicts $\mathrm{HO}_{2}$ beyond 5 ppbv NO by up to a factor of 10 at the highest NO experienced (see the 52 ppbv NO bin, Fig. 6, which includes NO mixing ratios up to $104 \mathrm{ppbv}$ ). The model under-predicts the observed $\mathrm{RO}_{2}$ over the whole NO range, and, consis- 


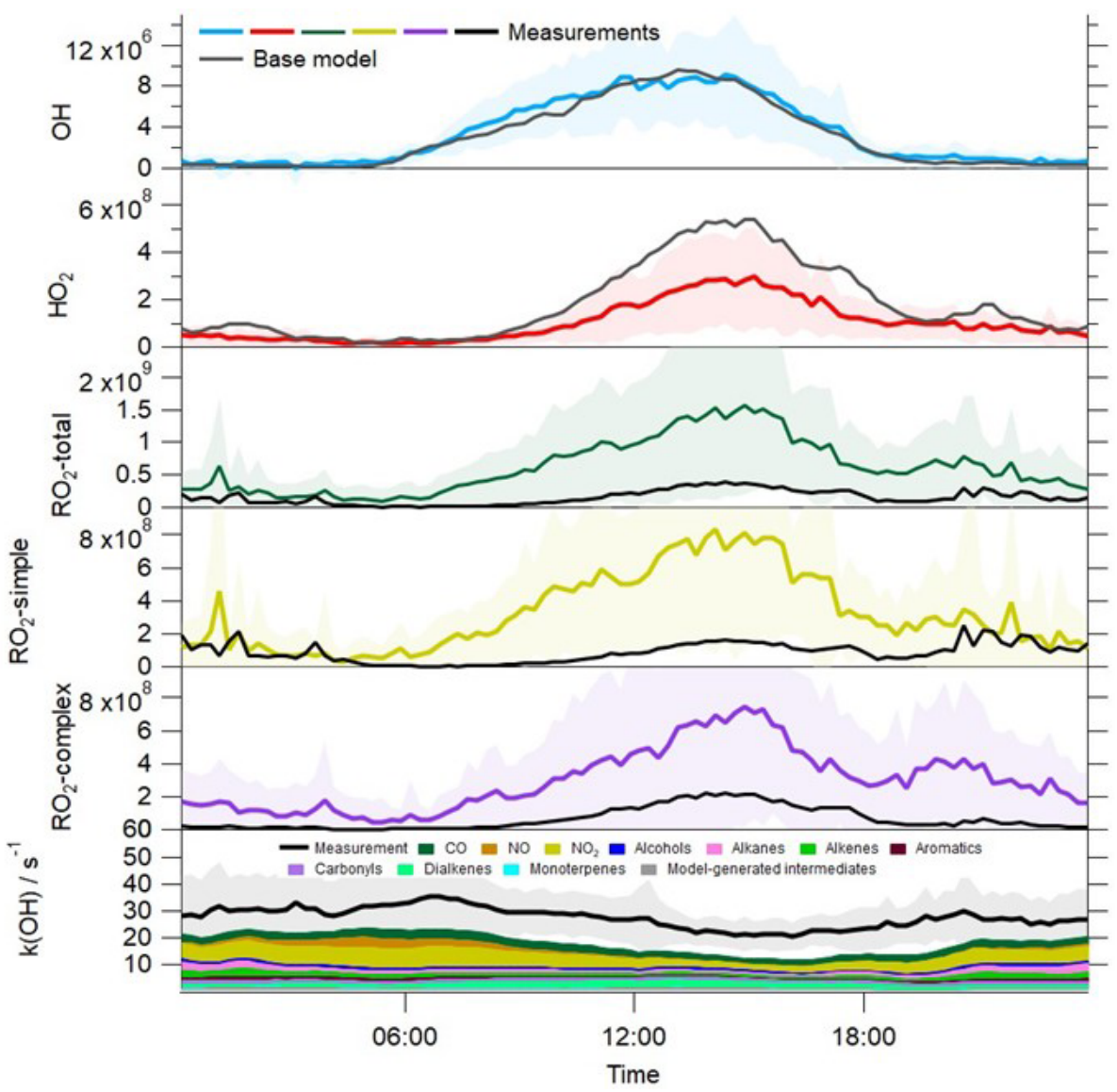

Figure 5. Average profiles for the observed $\mathrm{OH}, \mathrm{HO}_{2}$, total $\mathrm{RO}_{2}$, partially speciated $\mathrm{RO}_{2}$ (in molecule $\mathrm{cm}^{-3}$ ) and $\mathrm{OH}$ reactivity at 15 min intervals over $24 \mathrm{~h}$. The error bars represent the $1 \sigma$ standard deviation of the measurements, representing the variability in the measurements from day to day. The average diurnal profiles for $\mathrm{OH}, \mathrm{HO}_{2}$, total $\mathrm{RO}_{2}$, partially speciated $\mathrm{RO}_{2}$ and $\mathrm{OH}$ reactivity from the base model are overlaid.

tent with the $\mathrm{RO}_{2}$ budget analysis, the under-prediction (in terms of \%) is greatest at the highest NO concentrations experienced during the morning hours. The model underpredicts the observed $\mathrm{RO}_{2}$ by a factor of $\approx 70$ in the highest NO mixing ratio bin range, whereas the destruction rate of $\mathrm{RO}_{2}$ exceeded the production rate by a factor of $\approx 10$ in the budget analysis. This large under-prediction of $\mathrm{RO}_{2}$ by the model under the highest NO concentrations is most likely driving the differences noted between the $\mathrm{P}$ to $\mathrm{D}\left(\mathrm{HO}_{2}\right)$ and the measured to modelled $\left(\mathrm{HO}_{2}\right)$ ratios at $\mathrm{NO}$ mixing ratios $>5$ ppbv. Previous radical studies made at urban sites which were influenced by a range of $\mathrm{NO}_{x}$ concentrations have demonstrated that the level of agreement between model predictions and the observations tends to vary with the level of NO: models have a tendency to under-predict the observed $\mathrm{OH}$ concentrations at $\mathrm{NO}$ mixing ratios below $1 \mathrm{ppbv}$ (Lu et al., 2012, 2013; Tan et al., 2017; Whalley et al., 2018), and $\mathrm{RO}_{2}$ concentrations are increasingly under-predicted as NO concentrations rise (Tan et al., 2017; Whalley et al., 2018; Slater et al., 2020).
$\mathrm{Cl}$ atoms, formed from the photolysis of nitryl chloride $\left(\mathrm{ClNO}_{2}\right)$, have been shown to act as a source of $\mathrm{RO}_{2}$ (Riedel et al., 2014; Bannan et al., 2015; Tan et al., 2017) and have also been investigated here to see if $\mathrm{Cl}$ chemistry can resolve the modelled $\mathrm{RO}_{2}$ under-prediction under the elevated NO concentrations which were typically observed during the mornings. $\mathrm{ClNO}_{2}$ was measured for part of the campaign (Zhou et al., 2018) and reached up to $1.44 \mathrm{ppbv}$ during the night on 12-13 June. The $\mathrm{Cl}$ atom concentration exceeded $4 \times 10^{4}$ atoms $\mathrm{cm}^{-3}$ during the morning of 13 June and exceeded $1 \times 10^{4}$ atoms $\mathrm{cm}^{-3}$ on several other mornings (Fig. 7). The $\mathrm{Cl}$ atom concentration was calculated from the concentration of $\mathrm{ClNO}_{2}$, its photolysis rate to yield $\mathrm{Cl}$ (determined from the observed actinic flux and published absorption cross section of $\mathrm{ClNO}_{2}$ ) and the VOC loading. During these times, the modelled $\mathrm{RO}_{2}$ concentrations increased, relative to the concentration in the base model, by up to $2.5 \times 10^{8}$ molecule $\mathrm{cm}^{-3}$, which represents close to a $100 \%$ increase in the modelled $\mathrm{RO}_{2}$ at these times. On several mornings (4, 5, 7 and 13 June) this increase in $\mathrm{RO}_{2}$ brought the model and measured $\mathrm{RO}_{2}$ into close agreement. 

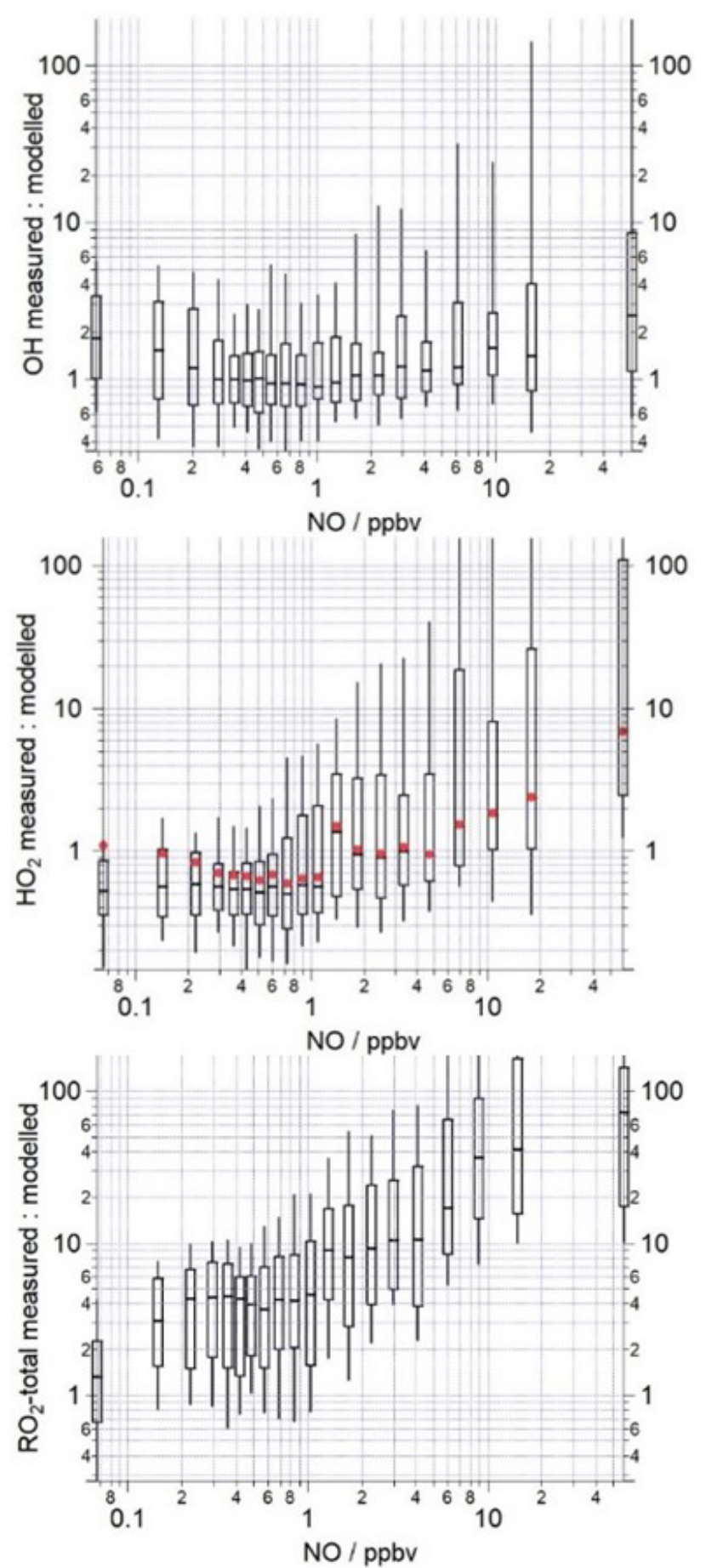

Figure 6. The median ratio (-) of the measured to modelled $\mathrm{OH}$, $\mathrm{HO}_{2}$ and total $\mathrm{RO}_{2}$ binned over the NO mixing ratio range encountered during the campaign on a logarithmic scale. The box and whiskers represent the 25 th and 75 th and the 5th and 95th confidence intervals. The red circles in the middle panel display the measured to modelled $\mathrm{HO}_{2}$ ratio when the model includes a heterogeneous loss of $\mathrm{HO}_{2}$ to aerosols calculated using Eq. (9). The number of data points in each of the NO bins is $\approx 80$.
The production rate of $\mathrm{RO}_{2}$ from Cl-initiated VOC oxidation on these mornings would serve to enhance $\mathrm{P}\left(\mathrm{RO}_{x}\right)$ by up to $2.1 \mathrm{ppbvh}^{-1}$. However, on several nights, only low concentrations of $\mathrm{ClNO}_{2}$ were measured, and only very low concentrations of $\mathrm{Cl}$ atoms were calculated to be present upon sunrise, and so, on these days, only modest enhancements $(1-2 \times$ $10^{7}$ molecule $\mathrm{cm}^{-3}$ ) in $\mathrm{RO}_{2}$ concentrations were predicted by the model, and the large under-prediction in the $\mathrm{RO}_{2}$ concentration on these mornings remained, which may indicate that there are other, overlooked, primary $\mathrm{RO}_{x}$ sources in the experimental budget calculation besides missing $\mathrm{Cl}+\mathrm{VOC}$ reactions. The $\mathrm{Cl}$ atom concentration dropped off rapidly during the mornings with just $\approx 100$ atoms $\mathrm{cm}^{-3}$ present by noon on most days and so was unable to reconcile the magnitude of the $\mathrm{RO}_{2}$ underestimation observed throughout the day.

\subsection{Rate of production and rate of destruction analysis}

A rate of production and rate of destruction analysis on model $\mathrm{OH}, \mathrm{HO}_{2}$ and $\mathrm{RO}_{2}$ species (Fig. 8) highlights the main radical sources and sinks in the base model. Consistent with earlier studies of radicals in urban locations, the photolysis of HONO is the dominant primary source of radicals during the daytime, accounting for $\approx 64 \%$ of the primary radical production on average during the day (05:0019:30) throughout the campaign. The photolysis of $\mathrm{O}_{3}$ and subsequent reaction of $\mathrm{O}\left({ }^{1} \mathrm{D}\right)$ with $\mathrm{H}_{2} \mathrm{O}$ vapour accounts for $\approx 9 \%$ of primary production during the day, whilst the photolysis of $\mathrm{HCHO}$ and other photo-labile VOCs accounts for $\approx 11 \%$ of the radical production. Ozonolysis and nitrate radical $\left(\mathrm{NO}_{3}\right)$ reactions account for $9 \%$ and $7 \%$ of the total radical production during the day, respectively. At night, both ozonolysis $(\approx 18 \%)$ and nitrate radical reactions $(\approx 82 \%)$ are the source of radicals. The primary source of radicals from $\mathrm{VOC}+\mathrm{NO}_{3}$ reactions is $\approx 1 \mathrm{ppbvh}^{-1}$ during the night, which is sufficient to close the $\mathrm{RO}_{x}$ experimental budget (Fig. 3).

Figure 9 highlights the rates of propagation in the model which transform $\mathrm{OH}$ to $\mathrm{HO}_{2}$ and $\mathrm{RO}_{2}, \mathrm{RO}_{2}$ to $\mathrm{HO}_{2}$ and $\mathrm{HO}_{2}$ back to $\mathrm{OH}$. The rate of propagation is rapid, and the secondary source of $\mathrm{OH}$ from $\mathrm{HO}_{2}+\mathrm{NO}$ is more than twice as large as the primary production of $\mathrm{OH}$ from $\mathrm{HONO}$ photolysis. Approximately one-third of the $\mathrm{OH}$ reacts with $\mathrm{CO}, \mathrm{O}_{3}$ or $\mathrm{HCHO}$ to form $\mathrm{HO}_{2}$, just over one-third reacts with VOCs to form $\mathrm{RO}_{2}$ and just under one-third is lost by reaction with $\mathrm{NO}_{2}$ forming nitric acid. In contrast to London (Whalley et al., 2018), the majority of $\mathrm{RO}_{2}$ formed during AIRPRO propagates to $\mathrm{HO}_{2}$, and subsequently the majority of $\mathrm{HO}_{2}$ propagates back to $\mathrm{OH}$. From the model radical flux analysis, which takes into consideration the different types of $\mathrm{RO}_{2}$ species present, a value of $\alpha=0.87$ is derived (where $\alpha=1$ minus the rate at which $\mathrm{RO}$ forms $\mathrm{RO}_{2}$ or $\mathrm{RC}(\mathrm{O}) \mathrm{O}_{2}$ divided by the rate of RO conversion to $\mathrm{HO}_{2}$ ). Note that this fraction does not consider $\mathrm{RO}_{2}$ and $\mathrm{RC}(\mathrm{O}) \mathrm{O}_{2}$ termination reac- 


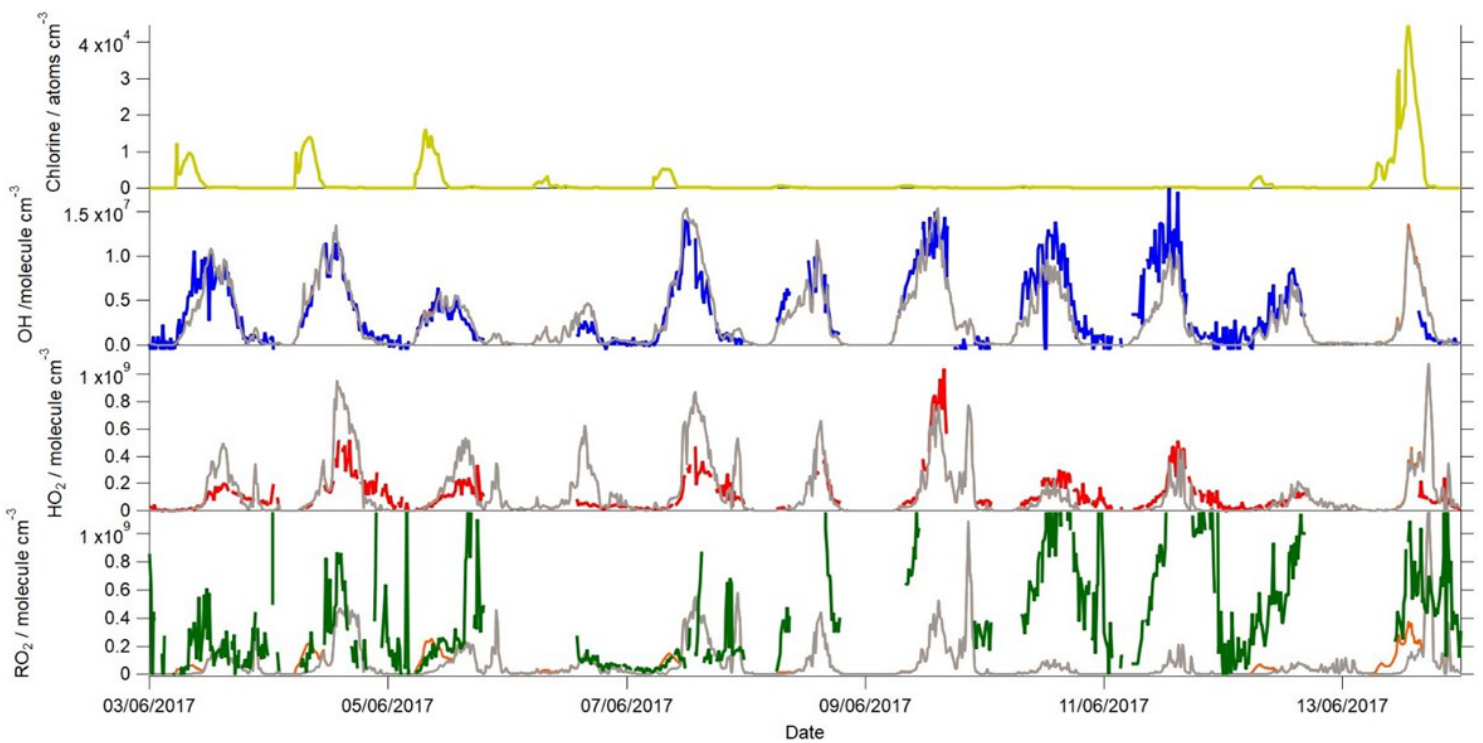

Figure 7. Time series of the measured and modelled $\mathrm{OH}, \mathrm{HO}_{2}$ and total $\mathrm{RO}_{2}$ during the campaign when $\mathrm{ClNO}_{2}$ was also measured. The $\mathrm{Cl}$ atom concentration calculated to be present is shown in the top panel. The measured $\mathrm{OH}$ concentrations are represented by the blue line, $\mathrm{HO}_{2}$ by the red line and total $\mathrm{RO}_{2}$ by the green line. The base model scenario is shown in grey, whilst the base model with $\mathrm{Cl}$ atom chemistry included (Xue et al., 2015) is shown in orange (only evident in the $\mathrm{RO}_{2}$ panel).
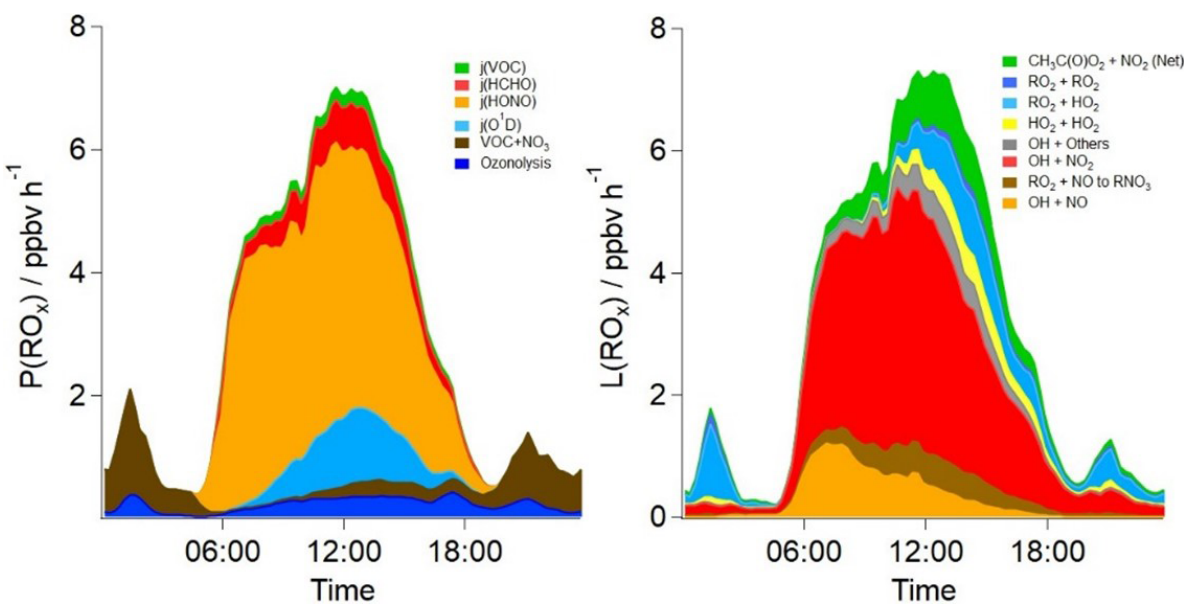

Figure 8. The average diurnal rates of primary production and termination for $\mathrm{RO}_{x}$ radicals in parts per billion per hour (ppbv $\mathrm{h}^{-1}$ ) in the base model scenario. $\mathrm{CH}_{3} \mathrm{C}(\mathrm{O}) \mathrm{O}_{2}+\mathrm{NO}_{2}(\mathrm{Net})$ represents the net rate (forward minus backward) for all $\mathrm{RC}(\mathrm{O}) \mathrm{O}_{2}+\mathrm{NO}_{2} \leftrightarrow \mathrm{PAN}$ species .

tions. In London, the model-derived $\alpha$ was $\approx 0.5$, reflecting the presence of long-chain alkane-derived $\mathrm{RO}_{2}$ species from diesel emissions and monoterpenes. In Beijing, measurement of such long-chain VOC species could not be attempted, but these could have been present. A lumped monoterpene signal was measured by PTR-ToF-MS and is included in the model, split equally between $\alpha$-pinene and limonene. The base model, on which the radical flux analysis was performed, under-predicts $\mathrm{OH}$ reactivity and so is likely missing $\mathrm{RO}_{2}$ species from additional $\mathrm{OH}+\mathrm{VOC}$ reactions, which, depending on the $\mathrm{RO}_{2}$ type, may serve to reduce $\alpha$.

\section{6 $\mathrm{OH}$ reactivity and missing $\mathrm{OH}$ reactivity}

$\mathrm{NO}_{2}$ was the single biggest contributor to the $\mathrm{OH}$ reactivity in Beijing, with a campaign average contribution of $18.6 \%$ (Fig. 5). This is similar to the $\mathrm{NO}_{2}$ contribution to $\mathrm{OH}$ reactivity observed in London (Whalley et al., 2016). NO contributed just $1.3 \%$ to the total reactivity in Beijing, compared to a $4.2 \%$ contribution in London (Whalley et al., 2016). In London, measured carbonyl species accounted for close to $20 \%$ of the $\mathrm{OH}$ reactivity budget, largely due to the high concentrations of HCHO (Whalley et al., 2016). In contrast, in Beijing, carbonyls accounted for just $3.8 \%$ of the mea- 


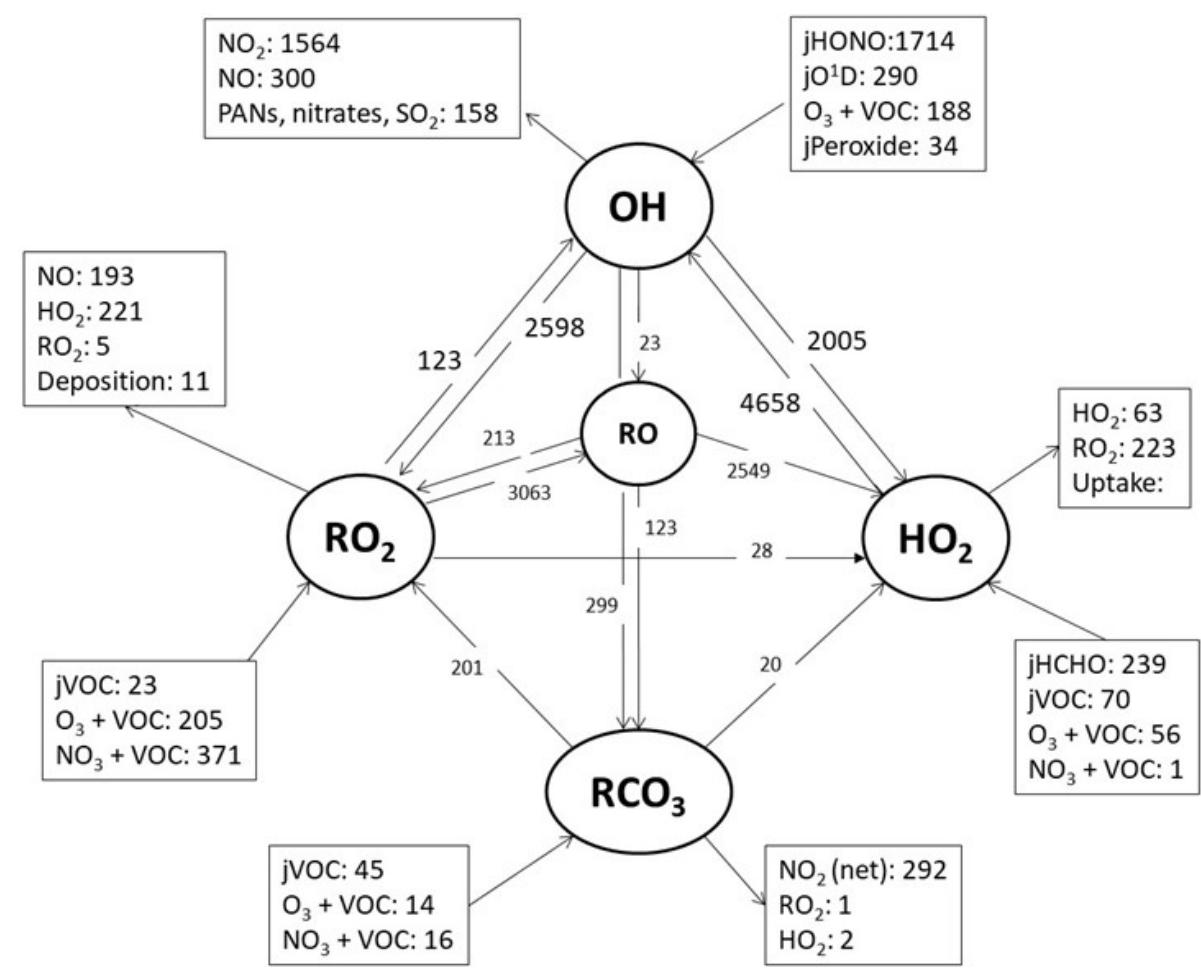

Figure 9. A model reaction flux analysis, showing the mean rate of reaction for formation, propagation and termination of radicals ( $\mathrm{pptv}^{-1}$ ) (day and night) during the whole campaign.

sured $k(\mathrm{OH})$. Alkenes and dialkenes were more prevalent in Beijing than in London, and the dialkene group of VOCs (dominated by isoprene) accounted for $10.5 \%$ of the $\mathrm{OH}$ reactivity in Beijing compared to $1.8 \%$ in London (Whalley et al., 2016). Owing to the faster physical loss of secondary species in Beijing by ventilation compared to London (see Sect. 2), the contribution that model-generated intermediate species made to the observed $\mathrm{OH}$ reactivity was $2.7 \%$ in Beijing vs. $23.8 \%$ in London (Whalley et al., 2016). In contrast to Beijing, where approximately $30 \%$ of the measured reactivity remains unaccounted for, in London, the $\mathrm{OH}$ reactivity budget was largely closed (Whalley et al., 2016). In Beijing during the measurement period when the missing $\mathrm{OH}$ reactivity reached on average $13 \mathrm{~s}^{-1}$ (15-22 June), isoprene concentrations were elevated relative to earlier in the campaign (Fig. 1). Overall, much higher concentrations of isoprene were observed in Beijing than in London (Whalley et al., 2016), and so this may indicate that other biogenic species that were not measured, along with their oxidation products, may account for some of the missing $\mathrm{OH}$ reactivity in Beijing.

A series of model simulations have been performed, whereby an additional $\mathrm{OH}$ to $\mathrm{RO}_{2}$ reaction has been included to account for the missing reactivity at a given time (Fig. 10); the $\mathrm{RO}_{2}$ formed has been varied to investigate the influence of different $\mathrm{RO}_{2}$ types on the modelled radical concentrations. When $\mathrm{OH}$ converts to methyl peroxy radicals, the mod- elled $\mathrm{RO}_{2}$ concentration increases by close to a factor of 2 on average, but just over a factor-of- 2 under-prediction of the observed $\mathrm{RO}_{2}$ radicals remains. Unsurprisingly, it is the modelled fraction of $\mathrm{RO}_{2}$ radicals that do not act as an $\mathrm{HO}_{2}$ interference (simple $\mathrm{RO}_{2}$ ) that increase in this scenario, and the model now only underestimates this class of $\mathrm{RO}_{2}$ species by a factor of 1.45 , whilst complex $\mathrm{RO}_{2}$ is still underestimated by a factor of 6.2. When $\mathrm{OH}$ converts to $\mathrm{HOCH}_{2} \mathrm{CH}_{2} \mathrm{O}_{2}$ (an $\mathrm{RO}_{2}$ species that does act as an $\mathrm{HO}_{2}$ interference, formed from the reaction of $\mathrm{OH}$ with ethene), the modelled complex $\mathrm{RO}_{2}$ fraction increases, and the model underestimation of complex $\mathrm{RO}_{2}$ is reduced to a factor of 1.8 on average, with the largest under-predictions observed during the evening hours. In both these model simulations, the modelled overprediction of $\mathrm{HO}_{2}$ increases from the base model scenario as $\mathrm{CH}_{3} \mathrm{O}_{2}$ and $\mathrm{HOCH}_{2} \mathrm{CH}_{2} \mathrm{O}_{2}$ both rapidly propagate to $\mathrm{HO}_{2}$. The modelled $\mathrm{OH}$ concentration displays a modest decrease with the additional $\mathrm{OH}$ sink; however, this is largely compensated for by the increase in modelled $\mathrm{HO}_{2}$, which enhances the secondary source of $\mathrm{OH}$ from $\mathrm{HO}_{2}+\mathrm{NO}$, and so, overall, the modelled $\mathrm{OH}$ concentration is largely buffered by the inclusion of missing $\mathrm{OH}$ reactivity in the form of additional methane (leading to $\mathrm{CH}_{3} \mathrm{O}_{2}$ ) or ethene (leading to $\mathrm{HOCH}_{2} \mathrm{CH}_{2} \mathrm{O}_{2}$ ).

Model simulations (not shown) which include an additional source of $\mathrm{CH}_{3} \mathrm{C}(\mathrm{O}) \mathrm{O}_{2}$, for example, from additional $\mathrm{CH}_{3} \mathrm{CHO}+\mathrm{OH}$ reactions, do predict substantially less $\mathrm{HO}_{2}$ 


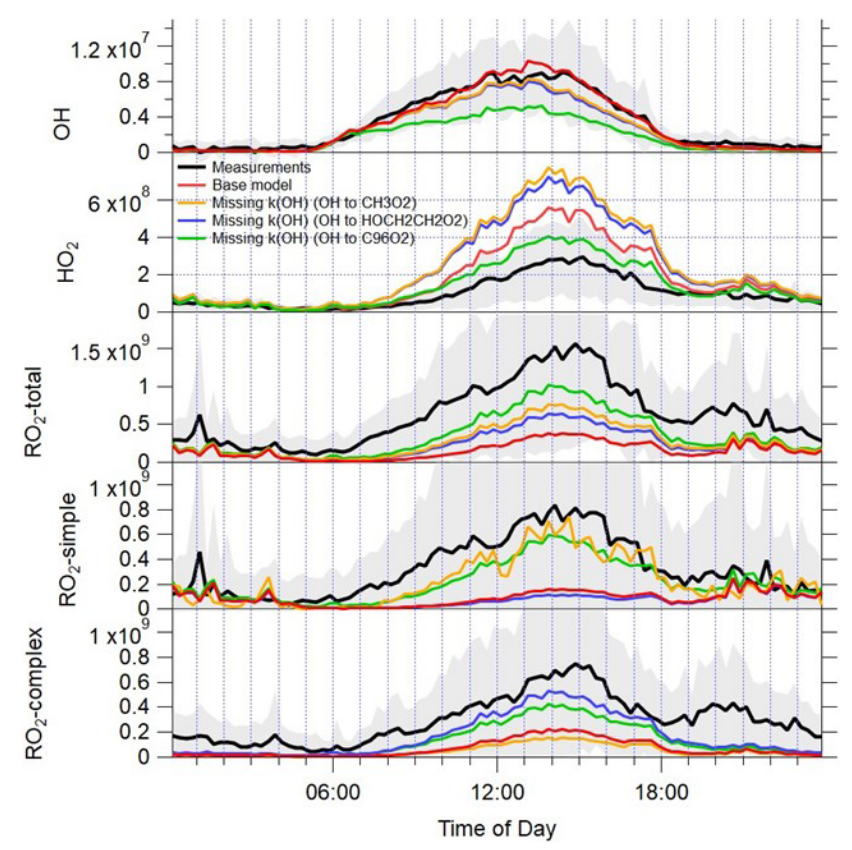

Figure 10. Average diel profiles for the observed $\mathrm{OH}, \mathrm{HO}_{2}$, total $\mathrm{RO}_{2}$ and partially speciated $\mathrm{RO}_{2}$ (black lines) at 15 min intervals over $24 \mathrm{~h}$. The error bars represent the $1 \sigma$ standard deviation of the measurements. The average $\mathrm{OH}, \mathrm{HO}_{2}$, total $\mathrm{RO}_{2}$ and partially speciated $\mathrm{RO}_{2}$ model profiles when the missing reactivity observed at a given time is accounted for by different $\mathrm{OH}$ to $\mathrm{RO}_{2}$ reactions are overlaid (yellow, blue and green lines); the base model predictions are in red. See text for details.

(and can reconcile the observed $\mathrm{HO}_{2}$ to with $25 \%$ ), but modelled $\mathrm{RO}_{2}$ concentrations do not increase as a large fraction of the acyl- $\mathrm{RO}_{2}$ radicals react with $\mathrm{NO}_{2}$ to form PAN and are, therefore, lost. These missing reactivity model simulations and measurement comparisons suggest that the missing $\mathrm{RO}_{2}$ may be a species, which, upon reaction with $\mathrm{NO}$, converts from one $\mathrm{RO}_{2}$ species to another and, therefore, competes with $\mathrm{RO}_{2}$ to $\mathrm{HO}_{2}$ propagation rather than a $\mathrm{RO}_{2}$ radical, which leads to $\mathrm{RO}_{2}$ termination. This suggests that the overall lifetime of $\mathrm{RO}_{2}$ radicals is longer than currently estimated and that multiple conversions of one $\mathrm{RO}_{2}$ species to another may be occurring to sustain the high concentrations observed. As identified in London, larger, more complex VOC species such as monoterpenes or long-chain alkanes deriving from diesel emissions do undergo multiple $\mathrm{RO}_{2}$ to $\mathrm{RO}_{2}$ conversions in the presence of $\mathrm{NO}$ as the alkoxy radical formed preferentially undergoes isomerisation rather than an external $\mathrm{H}$ atom abstraction by $\mathrm{O}_{2}$. If an additional reaction which converts $\mathrm{OH}$ to an $\mathrm{RO}_{2}$ species formed during the oxidation of $\alpha$-pinene, and which undergoes four reactions with $\mathrm{NO}$ before eventually forming $\mathrm{HO}_{2}$, is added to the model at a rate sufficient to reconcile the missing $\mathrm{OH}$ reactivity, the model predicts significantly more total $\mathrm{RO}_{2}$ and now only modestly under-predicts the observed $\mathrm{RO}_{2}$ concentrations (by a factor of 1.8). The modelled radical concentra- tions predicted from the "missing $k(\mathrm{OH})(\mathrm{OH}$ to $\mathrm{C} 96 \mathrm{O} 2)$ " scenario are overlaid with the radical observations and modelled radicals from the base model scenario in Fig. S2. The additional VOC reactivity which produces $\mathrm{RO}_{2}$ radicals that isomerise after reaction with $\mathrm{NO}$ is able to increase the modelled total $\mathrm{RO}_{2}$ concentration, both under the lower NO conditions experienced between 15-22 June and on the higher NO days (9-12 June), indicating that NO is still at sufficient concentrations to dominate the fate of $\mathrm{RO}_{2}$ between 15-22 June, despite NO concentrations being lower. The median measured to modelled (missing $k(\mathrm{OH})(\mathrm{OH}$ to $\mathrm{C} 96 \mathrm{O} 2)$ ) ratio vs. NO (Fig. S3) highlights that the inclusion of alkoxy isomerisation following the $\mathrm{RO}_{2}+\mathrm{NO}$ reaction increases the modelled $\mathrm{RO}_{2}$ across the entire $\mathrm{NO}$ range but, considering the log scale, has the biggest impact on the ratio (from the measured to modelled (base) ratio) at the highest NO concentration. Both the simple and complex $\mathrm{RO}_{2}$ species are enhanced, as the first three generations of $\mathrm{RO}_{2}$ species formed would be detected during the $\mathrm{RO}_{x}$ mode in the $\mathrm{RO}_{x}$ LIF instrument and, hence, contribute to simple $\mathrm{RO}_{2}$. The final $\mathrm{RO}_{2}$ species formed, that does propagate to $\mathrm{HO}_{2}$ via $\mathrm{RO}$ upon reaction with $\mathrm{NO}$, would be detected during the $\mathrm{HO}_{x}$ mode in the $\mathrm{RO}_{x}$ LIF instrument and, as such, contributes to the complex $\mathrm{RO}_{2}$ fraction. In this scenario, the $\mathrm{HO}_{2}$ concentration is now only modestly overestimated by a factor of 1.4. The $\mathrm{RO}_{x}$ LIF instrument relies on the conversion of $\mathrm{RO}_{2}$ species to $\mathrm{HO}_{2}$ (and ultimately to $\mathrm{OH}$ ) for detection, so one might expect the instrument to be insensitive to $\mathrm{RO}_{2}$ species that do not directly propagate to $\mathrm{RO}$ then to $\mathrm{HO}_{2}$ upon reaction with NO. However, given the $\mathrm{RO}_{x}$ LIF flow tube conditions (NO concentration of $4 \times 10^{13}$ molecule $\mathrm{cm}^{-3}$ and residence time of just under $1 \mathrm{~s}), \mathrm{RO}_{2}$ species that require several reactions with $\mathrm{NO}$ before $\mathrm{HO}_{2}$ is produced should still be detected. These types of $\mathrm{RO}_{2}$ species that require more than one reaction with $\mathrm{NO}$ before $\mathrm{HO}_{2}$ forms may be generated via the additional $\mathrm{VOC}+\mathrm{OH}$ reactions identified as missing $\mathrm{OH}$ reactivity (as presented here). They may also be present due to a missing primary source of $\mathrm{RO}_{2}$ such as decomposition of a complex PAN species, VOC photolysis, a $\mathrm{Cl}$ atom + VOC reaction or an alkene ozonolysis product. The experimental peroxy radical budget analysis highlighted that budget closure could only be achieved if $\alpha$ was reduced to 0.1 , which suggests that the model breakdown of peroxy radical species present (e.g. the fraction of acyl- $\mathrm{RO}_{2}$, long- vs. short-chained alkyl- $\mathrm{RO}_{2}$ species) may be incomplete. In the scenario in which $\mathrm{OH}$ converts to an $\alpha$-pinene-derived $\mathrm{RO}_{2}$ species, consistent with the experimental budget analysis, the model under-predicts the observed $\mathrm{OH}$ by a factor of 1.8 , revealing that there is a missing source of $\mathrm{OH}$ under the low NO conditions in Beijing that was previously masked by the model over-prediction of $\mathrm{HO}_{2}$. 


\subsection{Impact on ozone production}

Previous work, for example, by Tan et al. (2017), suggested that the addition of a primary $\mathrm{RO}_{2}$ source could help reconcile the model under-prediction of $\mathrm{RO}_{2}$. However, as demonstrated in Sect. 3.6, the identity of the primary $\mathrm{RO}_{2}$ is important, and in Beijing a complex $\mathrm{RO}_{2}$ species that has a large enough carbon skeleton such that the RO radical formed upon reaction with $\mathrm{NO}$ preferentially isomerises to another $\mathrm{RO}_{2}$ (and undergoes multiple $\mathrm{RO}_{2}$ to $\mathrm{RO}_{2}$ conversions before eventually forming $\mathrm{HO}_{2}$ ) is needed to reconcile both the observed $\mathrm{RO}_{2}$ and $\mathrm{HO}_{2}$ concentrations. These types of $\mathrm{RO}_{2}$ species may also preferentially isomerise rather than undergo the bimolecular reactions with NO if NO concentrations are low enough. For example, laboratory studies have shown that the monoterpenes, following an initial attack by ozone or $\mathrm{OH}$, form highly oxidised $\mathrm{RO}_{2}$ radicals within a few seconds via repeated $\mathrm{H}$ shift from $\mathrm{C}-\mathrm{H}$ to an $\mathrm{R}-\mathrm{O}-\mathrm{O}$ bond and subsequent $\mathrm{O}_{2}$ additions (Ehn et al., 2014; Jokinen et al., 2014; Berndt et al., 2016). Recently, autoxidation has also been shown to occur during the oxidation of aromatic VOCs too (S. N. Wang et al., 2017). Autoxidation reactions may generate $\mathrm{OH}$ directly from $\mathrm{RO}_{2}$ and, therefore, may also resolve the missing $\mathrm{OH}$ source reported under low NO conditions (here and in the literature). These types of autoxidation reactions lead to the generation of HOMs, which have also been shown to condense and contribute to SOA (Mohr et al., 2019). Mass spectrometric signals relating to these highly oxidised $\mathrm{RO}_{2}$ species were observed during the AIRPRO campaign (Brean et al., 2019; Mehra et al., 2021) suggesting that autoxidation was occurring at the Beijing site. Unimolecular $\mathrm{H}$ atom shifts are represented within the MCM3.3.1 for isoprene oxidation. Autoxidation reactions for other $\mathrm{RO}_{2}$ radicals are currently not included within the MCM3.3.1, although improved representation of $\mathrm{RO}_{2}$ radical chemistry is a focus for the next generation of explicit detailed chemical mechanisms (Jenkin et al., 2019). In addition to missing unimolecular $\mathrm{RO}_{2}$ reactions, the model may be missing other $\mathrm{RO}_{2}$ reaction pathways, for example, $\mathrm{RO}_{2}$ accretion reactions, as identified by Berndt et al. (2018). Although it is difficult to fully assess how competitive these $\mathrm{RO}_{2}+\mathrm{RO}_{2}$ reactions may be compared to $\mathrm{RO}_{2}+\mathrm{NO}$ reactions from the total $\mathrm{RO}_{2}$ observations made (the concentration of each individual $\mathrm{RO}_{2}$ would be needed), the inclusion of accretion reactions in the MCM would serve to reduce the modelled $\mathrm{RO}_{2}$ concentration under low $\mathrm{NO}_{x}$ conditions as the reaction represents an overall $\mathrm{RO}_{x}$ sink. This suggests that the missing $\mathrm{RO}_{2}$ source identified here may be even larger under the lower NO conditions.

The model measurement comparisons above suggest that our understanding of the rate at which the larger $\mathrm{RO}_{2}$ species propagate to $\mathrm{HO}_{2}$ (or to $\mathrm{OH}$ directly) and the possible reactions they undergo (which have not undergone substantial laboratory study) is far from complete and highlights that $\mathrm{RO}_{2}$ chemistry warrants further study. One important find- ing, however, is that the underestimation of the observed $\mathrm{RO}_{2}$ may be caused by missing reactions that compete with the $\mathrm{RO}_{2}+\mathrm{NO}$ reactions that form $\mathrm{HO}_{2}$. These competing reactions are effectively slowing the rate at which $\mathrm{RO}_{2}$ species convert to $\mathrm{HO}_{2}$, but if, as suggested here, these reactions are $\mathrm{RO}_{2}+\mathrm{NO}$ reactions that reform another $\mathrm{RO}_{2}$ radical, they will still be relevant in terms of ozone production. Under low NO conditions there is emerging evidence that unimolecular isomerisation reactions occur for a range of $\mathrm{RO}_{2}$ radicals (Ehn et al., 2014; Jokinen et al., 2014; Berndt et al., 2016; S. N. Wang et al., 2017) as well as $\mathrm{RO}_{2}$ accretion reactions (Berndt et al., 2018). These reactions will effectively remove $\mathrm{RO}_{2}$ radicals without conversion of $\mathrm{NO}$ to $\mathrm{NO}_{2}$ and so also have implications for modelling in situ $\mathrm{O}_{3}$ production, if models rely only on the rate of VOC oxidation when investigating $\mathrm{O}_{3}$ production.

By approximating the rate of ozone production to the rate of $\mathrm{NO}_{2}$ production from the reaction of $\mathrm{NO}$ with $\mathrm{HO}_{2}$ and $\mathrm{RO}_{2}$ radicals, urban radical measurements can be used to estimate chemical ozone formation (Kanaya et al., 2007; Ren et al., 2013; Brune et al., 2016; Tan et al., 2017; Whalley et al., 2018).

$$
\mathrm{P}\left(\mathrm{O}_{x}\right)=\left(k_{\mathrm{HO}_{2}+\mathrm{NO}}\left[\mathrm{HO}_{2}\right][\mathrm{NO}]+k_{\mathrm{RO}_{2}+\mathrm{NO}}\left[\mathrm{RO}_{2}\right][\mathrm{NO}]\right)
$$

Losses of $\mathrm{O}_{x}\left(\mathrm{~L}\left(\mathrm{O}_{x}\right)\right)$ include chemical losses such as the reaction of $\mathrm{NO}_{2}$ with $\mathrm{OH}$, net PAN formation, the fraction of $\mathrm{O}\left({ }^{1} \mathrm{D}\right)$ (formed by the photolysis of $\mathrm{O}_{3}$ ) that react with $\mathrm{H}_{2} \mathrm{O}$ and the reaction of $\mathrm{O}_{3}$ with $\mathrm{OH}$ and $\mathrm{HO}_{2}$. Physical loss processes, such as $\mathrm{O}_{3}$ deposition and ventilation out of the model box (see Sect. 2.4), will also contribute to $\mathrm{L}\left(\mathrm{O}_{x}\right)$. Physical processes such as advection of $\mathrm{O}_{3}$ into the model box would also need to be considered in the model to make a direct comparison to the observed $\mathrm{O}_{3}$ concentrations.

Considering the chemical production of $\mathrm{O}_{x}$ (Eq. 11), recent studies, in which $\mathrm{OH}, \mathrm{HO}_{2}$ and $\mathrm{RO}_{2}$ observations (via $\mathrm{RO}_{x}$ LIF) were made, demonstrated that models may underpredict ozone production at high NO due to an underestimation of the $\mathrm{RO}_{2}$ radical concentrations at high NO concentrations (Tan et al., 2017; Whalley et al., 2018). Figure 11 displays the mean ozone production calculated from the radical observations (red line) as a function of NO, and, consistent with the earlier ozone production calculations from the Wangdu (Tan et al., 2017) and London (Whalley et al., 2018) studies, the in situ ozone production calculated from the modelled $\mathrm{OH}$ and peroxy radicals (black line) is lower than from the observed radicals, most significantly at the higher NO concentrations. To accurately simulate ozone production and to understand how emission reduction policies may impact ozone levels, it is essential that the model accurately reflects the types of $\mathrm{RO}_{2}$ species present and how fast they propagate to another $\mathrm{RO}_{2}$ species or to $\mathrm{HO}_{2}$ or to $\mathrm{OH}$. 


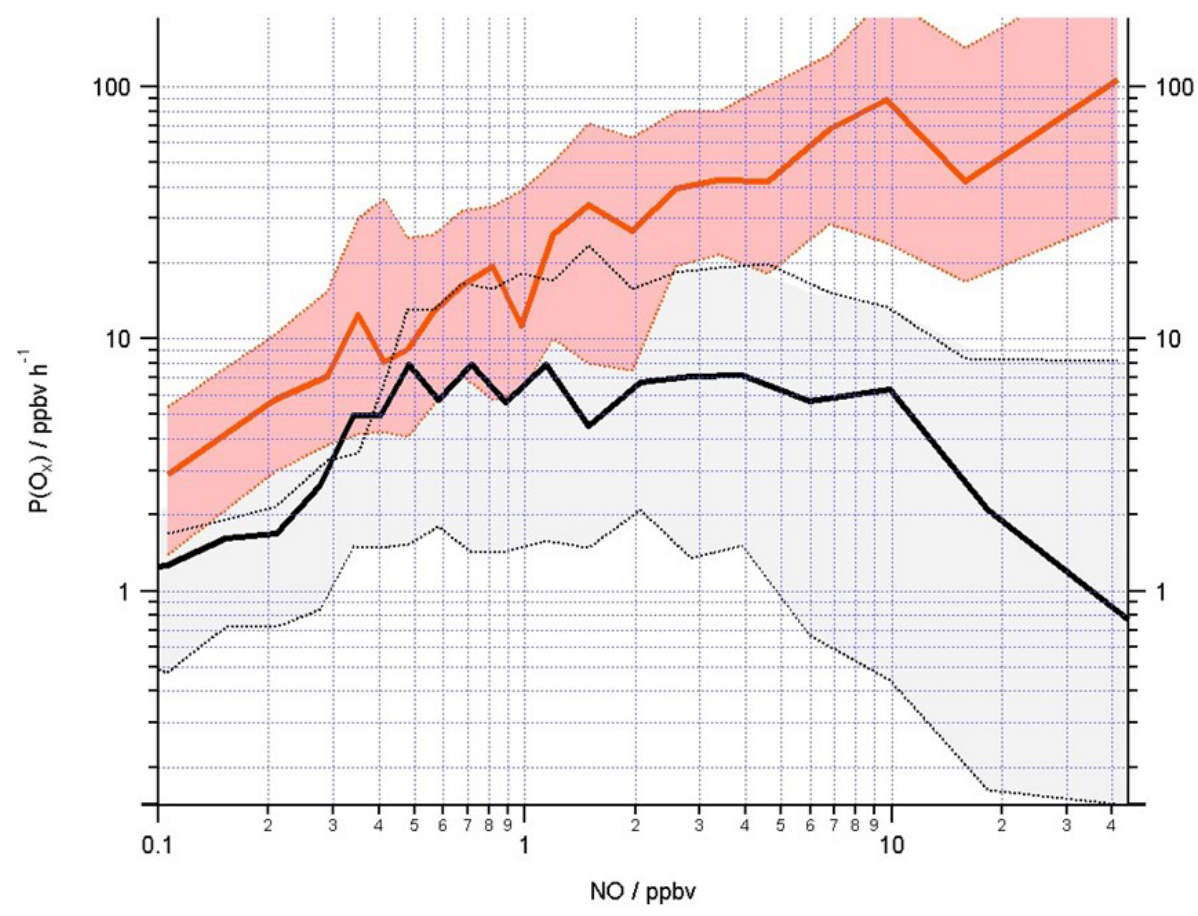

Figure 11. Mean $\mathrm{O}_{x}$ production ( $\mathrm{ppbvh}^{-1}$ ) calculated from observed (red line) and modelled (black line) $\mathrm{RO}_{x}$ concentrations using Eq. (11) binned over the NO mixing ratio range encountered during the campaign on a logarithmic scale. The shading represents the 25 th and 75 th percentile confidence limits. The number of data points in each of the NO bins is $\approx 80$.

\section{Conclusions}

Measurement and model comparisons of $\mathrm{OH}, \mathrm{HO}_{2}$, complex $\mathrm{RO}_{2}$, simple $\mathrm{RO}_{2}$ and total $\mathrm{RO}_{2}$ in Beijing have displayed varying levels of agreement as a function of $\mathrm{NO}_{x}$. Under low NO conditions, consistent with previous studies in low $\mathrm{NO}_{x}$ but high VOC environments, a missing $\mathrm{OH}$ source is evident. Radical budget analysis has demonstrated that this missing $\mathrm{OH}$ source could be resolved if unimolecular reactions of $\mathrm{RO}_{2}$ radicals generate $\mathrm{OH}$ directly. Under the low $\mathrm{NO}$ conditions $(<1 \mathrm{ppbv})$, the MCM over-predicted $\mathrm{HO}_{2}$, although this over-prediction could be resolved at very low NO mixing ratios $(<0.3 \mathrm{ppbv})$ by including a heterogeneous loss term to aerosol surfaces. This highlights that a reduction in aerosol surface area has the potential to enhance $\mathrm{HO}_{2}$ concentrations and thereby increase photochemical ozone formation but only under very low NO conditions. The model under-predicted $\mathrm{RO}_{2}$, most severely under high $\mathrm{NO}$ conditions ( $>1 \mathrm{ppbv}$ ). Although $\mathrm{Cl}$ atoms could increase the concentration of $\mathrm{RO}_{2}$, this enhancement was limited to times when the $\mathrm{Cl}$ atom concentration was elevated and could not resolve the $\mathrm{RO}_{2}$ under-prediction observed at all times. In the presence of $\mathrm{NO}$, the model overestimates the rate at which $\mathrm{RO}_{2}$ propagates to $\mathrm{HO}_{2}$, and we hypothesise that larger $\mathrm{RO}_{2}$ species likely undergo multiple bimolecular reactions with $\mathrm{NO}$, followed by isomerisation of the RO radical to another $\mathrm{RO}_{2}$ species, before a $\mathrm{HO}_{2}$ radical forms. By this process, the lifetime and the concentration of total $\mathrm{RO}_{2}$ radicals are extended. The ozone production efficiency of large, complex VOCs from which these $\mathrm{RO}_{2}$ species are formed may be greater than currently appreciated, and so further efforts to understand the rate at which the larger $\mathrm{RO}_{2}$ species propagate to $\mathrm{HO}_{2}$ (or to $\mathrm{OH}$ directly) and all the possible reactions they undergo are necessary to accurately model ozone levels in urban centres such as Beijing and to fully understand how emission controls will impact ozone.

Data availability. Data presented in this study are available from the author upon request (1.k.whalley@leeds.ac.uk).

Supplement. The supplement related to this article is available online at: https://doi.org/10.5194/acp-21-2125-2021-supplement.

Author contributions. LKW, EJS, RWM, CY and DEH carried out the measurements. LKW and EJS developed the model and performed the calculations. JDL, FS, JRH, RED, MS, JFH, ACL, AM, SDW, AB, TJB, HC, BO, RLJ, LRC, LJK, WJB, TV, SK, SG, YS, WX, SY, LR, WJFA, CNH, XW and PF provided logistical support and supporting data to constrain the model. LKW prepared the manuscript, with contributions from all the co-authors. 
Competing interests. The authors declare that they have no conflict of interest.

Special issue statement. This article is part of the special issue "In-depth study of air pollution sources and processes within Beijing and its surrounding region (APHH-Beijing) (ACP/AMT interjournal SI)". It is not associated with a conference.

Acknowledgements. Eloise Slater, Robert Woodward-Massey, Freya Squires and Archit Mehra acknowledge NERC SPHERES $\mathrm{PhD}$ studentships. We would like to thank Likun Xue and coauthors for providing the chlorine chemistry module used in the MCM. We acknowledge the support from Zifa Wang and Jie Li from the Institute of Applied Physics (IAP), Chinese Academy of Sciences, for hosting the APHH-Beijing campaign. We thank Liangfang Wei, Hong Ren, Qiaorong Xie, Wanyu Zhao, Linjie Li, Ping Li, Shengjie Hou and Qingqing Wang from IAP, Kebin He and Xiaoting Cheng from Tsinghua University and James Allan from the University of Manchester for providing logistic and scientific support for the field campaigns. We would also like to thank other participants in the APHH field campaign.

Financial support. This research has been supported by the Natural Environment Research Council (grant no. NE/N006895/1) and the National Natural Science Foundation of China (grant no. 41571130031).

Review statement. This paper was edited by Ronald Cohen and reviewed by two anonymous referees.

\section{References}

Bannan, T. J., Booth, A. M., Bacak, A., Muller, J. B. A., Leather, K. E., Le Breton, M., Jones, B., Young, D., Coe, H., Allan, J., Visser, S., Slowik, J. G., Furger, M., Prevot, A. S. H., Lee, J., Dunmore, R. E., Hopkins, J. R., Hamilton, J. F., Lewis, A. C., Whalley, L. K., Sharp, T., Stone, D., Heard, D. E., Fleming, Z. L., Leigh, R., Shallcross, D. E., and Percival, C. J.: The first UK measurements of nitryl chloride using a chemical ionization mass spectrometer in central London in the summer of 2012, and an investigation of the role of $\mathrm{Cl}$ atom oxidation, J. Geophys. Res. Atmos., 120, 5638-5657, https://doi.org/10.1002/2014JD022629, 2015.

Berndt, T., Richters, S., Jokinen, T., Hyttinen, N., Kurten, T., Otkjaer, R. V., Kjaergaard, H. G., Stratmann, F., Herrmann, H., Sipila, M., Kulmala, M., and Ehn, M.: Hydroxyl radical-induced formation of highly oxidized organic compounds, Nat. Commun., 7, 13677, https://doi.org/10.1038/Ncomms13677, 2016.

Berndt, T., Mentler, B., Scholz, W., Fischer, L., Herrmann, H., Kulmala, M., and Hansel, A.: Accretion product formation from ozonolysis and $\mathrm{OH}$ radical reaction of $\alpha$-pinene: Mechanistic insight and the influence of isoprene and ethylene, Environ. Sci. Technol., 52, 11069-11077, 2018.
Bigi, A. and Harrison, R. M.: Analysis of the air pollution climate at a central urban background site, Atmos. Environ., 44, 20042012, https://doi.org/10.1016/j.atmosenv.2010.02.028, 2010.

Brean, J., Harrison, R. M., Shi, Z., Beddows, D. C. S., Acton, W. J. F., Hewitt, C. N., Squires, F. A., and Lee, J.: Observations of highly oxidized molecules and particle nucleation in the atmosphere of Beijing, Atmos. Chem. Phys., 19, 14933-14947, https://doi.org/10.5194/acp-19-14933-2019, 2019.

Brune, W. H., Baier, B. C., Thomas, J., Ren, X., Cohen, R. C., Pusede, S. E., Browne, E. C., Goldstein, A. H., Gentner, D. R., Keutsch, F. N., Thornton, J. A., Harrold, S., Lopez-Hilfiker, F. D., and Wennberg, P. O.: Ozone production chemistry in the presence of urban plumes, Faraday Discuss., 189, 169-189, https://doi.org/10.1039/c5fd00204d, 2016.

Chatani, S., Shimo, N., Matsunaga, S., Kajii, Y., Kato, S., Nakashima, Y., Miyazaki, K., Ishii, K., and Ueno, H.: Sensitivity analyses of $\mathrm{OH}$ missing sinks over Tokyo metropolitan area in the summer of 2007, Atmos. Chem. Phys., 9, 8975-8986, https://doi.org/10.5194/acp-9-8975-2009, 2009.

Chen, R. J., Zhao, Z. H., and Kan, H. D.: Heavy Smog and Hospital Visits in Beijing, China, Am. J. Respir. Crit. Care Med., 188, 1170-1171, https://doi.org/10.1164/rccm.201304-0678LE, 2013.

Commane, R., Floquet, C. F. A., Ingham, T., Stone, D., Evans, M. J., and Heard, D. E.: Observations of $\mathrm{OH}$ and $\mathrm{HO}_{2}$ radicals over West Africa, Atmos. Chem. Phys., 10, 8783-8801, https://doi.org/10.5194/acp-10-8783-2010, 2010.

Crilley, L. R., Kramer, L. J., Ouyang, B., Duan, J., Zhang, W., Tong, S., Ge, M., Tang, K., Qin, M., Xie, P., Shaw, M. D., Lewis, A. C., Mehra, A., Bannan, T. J., Worrall, S. D., Priestley, M., Bacak, A., Coe, H., Allan, J., Percival, C. J., Popoola, O. A. M., Jones, R. L., and Bloss, W. J.: Intercomparison of nitrous acid (HONO) measurement techniques in a megacity (Beijing), Atmos. Meas. Tech., 12, 6449-6463, https://doi.org/10.5194/amt12-6449-2019, 2019.

Cryer, D. R.: Measurements of hydroxyl radical reactivity and formaldehyde in the atmosphere, $\mathrm{PhD}$, School of Chemistry, University of Leeds, UK, 2016.

Ehn, M., Thornton, J. A., Kleist, E., Sipila, M., Junninen, H., Pullinen, I., Springer, M., Rubach, F., Tillmann, R., Lee, B., Lopez-Hilfiker, F., Andres, S., Acir, I. H., Rissanen, M., Jokinen, T., Schobesberger, S., Kangasluoma, J., Kontkanen, J., Nieminen, T., Kurten, T., Nielsen, L. B., Jorgensen, S., Kjaergaard, H. G., Canagaratna, M., Dal Maso, M., Berndt, T., Petaja, T., Wahner, A., Kerminen, V. M., Kulmala, M., Worsnop, D. R., Wildt, J., and Mentel, T. F.: A large source of lowvolatility secondary organic aerosol, Nature, 506, 476-479, https://doi.org/10.1038/nature13032, 2014.

Fuchs, H., Holland, F. and Hofzumahaus, A.: Measurement of tropospheric $\mathrm{RO}_{2}$ and $\mathrm{HO}_{2}$ radicals by a laser-induced fluorescence instrument, Rev. Sci. Instrum., 79, 084104, https://doi.org/10.1063/1.2968712, 2008.

Fuchs, H., Tan, Z., Lu, K., Bohn, B., Broch, S., Brown, S. S., Dong, H., Gomm, S., Häseler, R., He, L., Hofzumahaus, A., Holland, F., Li, X., Liu, Y., Lu, S., Min, K.-E., Rohrer, F., Shao, M., Wang, B., Wang, M., Wu, Y., Zeng, L., Zhang, Y., Wahner, A., and Zhang, Y.: OH reactivity at a rural site (Wangdu) in the North China Plain: contributions from $\mathrm{OH}$ reactants and 
experimental OH budget, Atmos. Chem. Phys., 17, 645-661, https://doi.org/10.5194/acp-17-645-2017, 2017.

He, H., Liang, X.-Z., Sun, C., Tao, Z., and Tong, D. Q.: The long-term trend and production sensitivity change in the US ozone pollution from observations and model simulations, Atmos. Chem. Phys., 20, 3191-3208, https://doi.org/10.5194/acp20-3191-2020, 2020.

Hofzumahaus, A., Rohrer, F., Lu, K. D., Bohn, B., Brauers, T., Chang, C. C., Fuchs, H., Holland, F., Kita, K., Kondo, Y., Li, X., Lou, S. R., Shao, M., Zeng, L. M., Wahner, A., and Zhang, Y. H.: Amplified Trace Gas Removal in the Troposphere, Science, 324, 1702-1704, https://doi.org/10.1126/science.1164566, 2009.

Hopkins, J. R., Jones, C. E., and Lewis, A. C.: A dual channel gas chromatograph for atmospheric analysis of volatile organic compounds including oxygenated and monoterpene compounds, J. Environ. Monit., 13, 2268-2276, 2011.

Huang, J., Pan, X. C., Guo, X. B., and Li, G. X.: Health impact of China's Air Pollution Prevention and Control Action Plan: an analysis of national air quality monitoring and mortality data, Lancet Planet. Health, 2, E313-E323, https://doi.org/10.1016/S2542-5196(18)30141-4, 2018.

Huang, R. J., Zhang, Y. L., Bozzetti, C., Ho, K. F., Cao, J. J., Han, Y. M., Daellenbach, K. R., Slowik, J. G., Platt, S. M., Canonaco, F., Zotter, P., Wolf, R., Pieber, S. M., Bruns, E. A., Crippa, M., Ciarelli, G., Piazzalunga, A., Schwikowski, M., Abbaszade, G., Schnelle-Kreis, J., Zimmermann, R., An, Z. S., Szidat, S., Baltensperger, U., El Haddad, I., and Prevot, A. S. H.: High secondary aerosol contribution to particulate pollution during haze events in China, Nature, 514, 218-222, https://doi.org/10.1038/nature13774, 2014.

Huang, Z., Zhang, Y., Yan, Q., Zhang, Z., and Wang, X.: Real-time monitoring of respiratory absorption factors of volatile organic compounds in ambient air by proton transfer reaction time-offlight mass spectrometry, J. Hazard. Mat., 320, 547-555, 2016.

Jacob, D. J.: Heterogeneous chemistry and tropospheric ozone, Atmos. Environ., 34, 2131-2159, Doi https://doi.org/10.1016/S1352-2310(99)00462-8, 2000.

Jenkin, M. E., Young, J. C., and Rickard, A. R.: The MCM v3.3.1 degradation scheme for isoprene, Atmos. Chem. Phys., 15, 11433-11459, https://doi.org/10.5194/acp-15-11433-2015, 2015.

Jenkin, M. E., Valorso, R., Aumont, B., and Rickard, A. R.: Estimation of rate coefficients and branching ratios for reactions of organic peroxy radicals for use in automated mechanism construction, Atmos. Chem. Phys., 19, 7691-7717, https://doi.org/10.5194/acp-19-7691-2019, 2019.

Jokinen, T., Sipila, M., Richters, S., Kerminen, V. M., Paasonen, P., Stratmann, F., Worsnop, D., Kulmala, M., Ehn, M., Herrmann, H., and Berndt, T.: Rapid Autoxidation Forms Highly Oxidized $\mathrm{RO}_{2}$ Radicals in the Atmosphere, Angew. Chem. Int. Ed., 53, 14596-14600, https://doi.org/10.1002/anie.201408566, 2014.

Kanaya, Y., Cao, R. Q., Akimoto, H., Fukuda, M., Komazaki, Y., Yokouchi, Y., Koike, M., Tanimoto, H., Takegawa, N., and Kondo, Y.: Urban photochemistry in central Tokyo: 1. Observed and modeled $\mathrm{OH}$ and $\mathrm{HO}_{2}$ radical concentrations during the winter and summer of 2004, J. Geophys. Res. Atmos., 112, D21312, https://doi.org/10.1029/2007jd008670, 2007.

Li, K., Jacob, D. J., Liao, H., Shen, L., Zhang, Q., and Bates, K. H.: Anthropogenic drivers of 2013-2017 trends in summer sur- face ozone in China, Proc. Natl. Acad. Sci. USA, 116, 422-427, https://doi.org/10.1073/pnas.1812168116, 2019.

Lou, S., Holland, F., Rohrer, F., Lu, K., Bohn, B., Brauers, T., Chang, C. C., Fuchs, H., Häseler, R., Kita, K., Kondo, Y., Li, X., Shao, M., Zeng, L., Wahner, A., Zhang, Y., Wang, W., and Hofzumahaus, A.: Atmospheric $\mathrm{OH}$ reactivities in the Pearl River Delta - China in summer 2006: measurement and model results, Atmos. Chem. Phys., 10, 11243-11260, https://doi.org/10.5194/acp-10-11243-2010, 2010.

Lu, K. D., Rohrer, F., Holland, F., Fuchs, H., Bohn, B., Brauers, T., Chang, C. C., Häseler, R., Hu, M., Kita, K., Kondo, Y., Li, X., Lou, S. R., Nehr, S., Shao, M., Zeng, L. M., Wahner, A., Zhang, Y. H., and Hofzumahaus, A.: Observation and modelling of $\mathrm{OH}$ and $\mathrm{HO}_{2}$ concentrations in the Pearl River Delta 2006: a missing $\mathrm{OH}$ source in a VOC rich atmosphere, Atmos. Chem. Phys., 12, 1541-1569, https://doi.org/10.5194/acp-12-1541-2012, 2012.

Lu, K. D., Hofzumahaus, A., Holland, F., Bohn, B., Brauers, T., Fuchs, H., Hu, M., Häseler, R., Kita, K., Kondo, Y., Li, X., Lou, S. R., Oebel, A., Shao, M., Zeng, L. M., Wahner, A., Zhu, T., Zhang, Y. H., and Rohrer, F.: Missing OH source in a suburban environment near Beijing: observed and modelled $\mathrm{OH}$ and $\mathrm{HO}_{2}$ concentrations in summer 2006, Atmos. Chem. Phys., 13, 10571080, https://doi.org/10.5194/acp-13-1057-2013, 2013.

Lu, K. D., Rohrer, F., Holland, F., Fuchs, H., Brauers, T., Oebel, A., Dlugi, R., Hu, M., Li, X., Lou, S. R., Shao, M., Zhu, T., Wahner, A., Zhang, Y. H., and Hofzumahaus, A.: Nighttime observation and chemistry of $\mathrm{HO}_{x}$ in the Pearl River Delta and Beijing in summer 2006, Atmos. Chem. Phys., 14, 4979-4999, https://doi.org/10.5194/acp-14-4979-2014, 2014.

Lu, K. D., Guo, S., Tan, Z. F., Wang, H. C., Shang, D. J., Liu, Y. H., Li, X., Wu, Z. J., Hu, M., and Zhang, Y. H.: Exploring atmospheric free-radical chemistry in China: the self-cleansing capacity and the formation of secondary air pollution, Natl. Sci. Rev., 6, 579-594, https://doi.org/10.1093/nsr/nwy073, 2019.

Mao, J. Q., Ren, X. R., Chen, S. A., Brune, W. H., Chen, Z., Martinez, M., Harder, H., Lefer, B., Rappengluck, B., Flynn, J., and Leuchner, M.: Atmospheric oxidation capacity in the summer of Houston 2006: Comparison with summer measurements in other metropolitan studies, Atmos. Environ., 44, 4107-4115, https://doi.org/10.1016/j.atmosenv.2009.01.013, 2010.

Martinez, M., Harder, H., Kovacs, T. A., Simpas, J. B., Bassis, J., Lesher, R., Brune, W. H., Frost, G. J., Williams, E. J., Stroud, C. A., Jobson, B. T., Roberts, J. M., Hall, S. R., Shetter, R. E., Wert, B., Fried, A., Alicke, B., Stutz, J., Young, V. L., White, A. B., and Zamora, R. J.: $\mathrm{OH}$ and $\mathrm{HO}_{2}$ concentrations, sources, and loss rates during the Southern Oxidants Study in Nashville, Tennessee, summer 1999, J. Geophys. Res. Atmos., 108, 4617, https://doi.org/10.1029/2003jd003551, 2003.

Mehra, A., Canagaratna, M., Bannan, T., Worrall, S. D., Bacak, A., Priestley, M., Zhao, J., Xu, W., Wang, Y., Cheng, X., Wang, L., Hamilton, J., Chen, Q., Stark, H., Krechmer, J. E., Squires, F. A., Lee, J., Brean, J., Slater, E. J., Whalley, L. K., Heard, D. E., Ouyang, B., Acton, W. J., Hewitt, C. N., Wang, X., Liu, D., Jayne, J. T., Sun, Y., Fu, P., Worsnop, D., Allan, J., Percival, C., and Coe, H.: Using highly time-resolved online mass spectrometry to examine biogenic and anthropogenic contributions to organic aerosol in Beijing, Faraday Discuss., , https://doi.org/10.1039/d0fd00080a, 2021. 
Michoud, V., Kukui, A., Camredon, M., Colomb, A., Borbon, A., Miet, K., Aumont, B., Beekmann, M., Durand-Jolibois, R., Perrier, S., Zapf, P., Siour, G., Ait-Helal, W., Locoge, N., Sauvage, S., Afif, C., Gros, V., Furger, M., Ancellet, G., and Doussin, J. F.: Radical budget analysis in a suburban European site during the MEGAPOLI summer field campaign, Atmos. Chem. Phys., 12, 11951-11974, https://doi.org/10.5194/acp-12-119512012, 2012.

Mohr, C., Thornton, J. A., Heitto, A., Lopez-Hilfiker, F. D., Lutz, A., Riipinen, I., Hong, J., Donahue, N. M., Hallquist, M., Petaja, T., Kulmala, M., and Yli-Juuti, T.: Molecular identification of organic vapors driving atmospheric nanoparticle growth, Nat. Commun., 10, 4442, https://doi.org/10.1038/S41467-01912473-2, 2019.

Newland, M. J., Bryant, D. J., Dunmore, R. E., Bannan, T. J., Acton, W. J. F., Langford, B., Hopkins, J. R., Squires, F. A., Dixon, W., Drysdale, W. S., Ivatt, P. D., Evans, M. J., Edwards, P. M., Whalley, L. K., Heard, D. E., Slater, E. J., Woodward-Massey, R., Ye, C., Mehra, A., Worrall, S. D., Bacak, A., Coe, H., Percival, C. J., Hewitt, C. N., Lee, J. D., Cui, T., Surratt, J. D., Wang, X., Lewis, A. C., Rickard, A. R., and Hamilton, J. F.: Rainforest-like Atmospheric Chemistry in a Polluted Megacity, Atmos. Chem. Phys. Discuss. [preprint], https://doi.org/10.5194/acp-2020-35, in review, 2020.

Peeters, J., Nguyen, T. L., and Vereecken, L.: $\mathrm{HO}_{x}$ radical regeneration in the oxidation of isoprene, Phys. Chem. Chem. Phys., 11, 5935-5939, https://doi.org/10.1039/b908511d, 2009.

Peeters, J., Muller, J. F., Stavrakou, T., and Nguyen, V. S.: Hydroxyl Radical Recycling in Isoprene Oxidation Driven by Hydrogen Bonding and Hydrogen Tunneling: The Upgraded LIM1 Mechanism, J. Phys. Chem. A, 118, 8625-8643, https://doi.org/10.1021/jp5033146, 2014.

Reeves, C. E., Mills, G. P., Whalley, L. K., Acton, W. J. F., Bloss, W. J., Crilley, L. R., Grimmond, S., Heard, D. E., Hewitt, C. N., Hopkins, J. R., Kotthaus, S., Kramer, L. J., Jones, R. L., Lee, J. D., Liu, Y., Ouyang, B., Slater, E., Squires, F., Wang, X., WoodwardMassey, R., and Ye, C.: Observations of speciated isoprene nitrates in Beijing: implications for isoprene chemistry, Atmos. Chem. Phys. Discuss. [preprint], https://doi.org/10.5194/acp2019-964, in review, 2020.

Ren, X. R., Harder, H., Martinez, M., Lesher, R. L., Oliger, A., Shirley, T., Adams, J., Simpas, J. B., and Brune, W. H.: $\mathrm{HO}_{x}$ concentrations and $\mathrm{OH}$ reactivity observations in New York City during PMTACS-NY2001, Atmos. Environ., 37, 3627-3637, https://doi.org/10.1016/S1352-2310(03)00460-6, 2003.

Ren, X. R., van Duin, D., Cazorla, M., Chen, S., Mao, J. Q., Zhang, L., Brune, W. H., Flynn, J. H., Grossberg, N., Lefer, B. L., Rappengluck, B., Wong, K. W., Tsai, C., Stutz, J., Dibb, J. E., Jobson, B. T., Luke, W. T., and Kelley, P.: Atmospheric oxidation chemistry and ozone production: Results from SHARP 2009 in Houston, Texas, J. Geophys. Res. Atmos., 118, 5770-5780, https://doi.org/10.1002/jgrd.50342, 2013.

Riedel, T. P., Wolfe, G. M., Danas, K. T., Gilman, J. B., Kuster, W. C., Bon, D. M., Vlasenko, A., Li, S.-M., Williams, E. J., Lerner, B. M., Veres, P. R., Roberts, J. M., Holloway, J. S., Lefer, B., Brown, S. S., and Thornton, J. A.: An MCM modeling study of nitryl chloride $\left(\mathrm{ClNO}_{2}\right)$ impacts on oxidation, ozone production and nitrogen oxide partitioning in pol- luted continental outflow, Atmos. Chem. Phys., 14, 3789-3800, https://doi.org/10.5194/acp-14-3789-2014, 2014.

Sadanaga, Y., Yoshino, A., Watanabe, K., Yoshioka, A., Wakazono, Y., Kanaya, Y., and Kajii, Y.: Development of a measurement system of $\mathrm{OH}$ reactivity in the atmosphere by using a laserinduced pump and probe technique, Rev. Sci. Instrum., 75, 26482655, https://doi.org/10.1063/1.1775311, 2004.

Saunders, S. M., Jenkin, M. E., Derwent, R. G., and Pilling, M. J.: Protocol for the development of the Master Chemical Mechanism, MCM v3 (Part A): tropospheric degradation of nonaromatic volatile organic compounds, Atmos. Chem. Phys., 3, 161-180, https://doi.org/10.5194/acp-3-161-2003, 2003.

Shi, Z., Vu, T., Kotthaus, S., Harrison, R. M., Grimmond, S., Yue, S., Zhu, T., Lee, J., Han, Y., Demuzere, M., Dunmore, R. E., Ren, L., Liu, D., Wang, Y., Wild, O., Allan, J., Acton, W. J., Barlow, J., Barratt, B., Beddows, D., Bloss, W. J., Calzolai, G., Carruthers, D., Carslaw, D. C., Chan, Q., Chatzidiakou, L., Chen, Y., Crilley, L., Coe, H., Dai, T., Doherty, R., Duan, F., Fu, P., Ge, B., Ge, M., Guan, D., Hamilton, J. F., He, K., Heal, M., Heard, D., Hewitt, C. N., Hollaway, M., Hu, M., Ji, D., Jiang, X., Jones, R., Kalberer, M., Kelly, F. J., Kramer, L., Langford, B., Lin, C., Lewis, A. C., Li, J., Li, W., Liu, H., Liu, J., Loh, M., Lu, K., Lucarelli, F., Mann, G., McFiggans, G., Miller, M. R., Mills, G., Monk, P., Nemitz, E., O’Connor, F., Ouyang, B., Palmer, P. I., Percival, C., Popoola, O., Reeves, C., Rickard, A. R., Shao, L., Shi, G., Spracklen, D., Stevenson, D., Sun, Y., Sun, Z., Tao, S., Tong, S., Wang, Q., Wang, W., Wang, X., Wang, X., Wang, Z., Wei, L., Whalley, L., Wu, X., Wu, Z., Xie, P., Yang, F., Zhang, Q., Zhang, Y., Zhang, Y., and Zheng, M.: Introduction to the special issue "In-depth study of air pollution sources and processes within Beijing and its surrounding region (APHH-Beijing)", Atmos. Chem. Phys., 19, 7519-7546, https://doi.org/10.5194/acp19-7519-2019, 2019.

Slater, E. J., Whalley, L. K., Woodward-Massey, R., Ye, C., Lee, J. D., Squires, F., Hopkins, J. R., Dunmore, R. E., Shaw, M., Hamilton, J. F., Lewis, A. C., Crilley, L. R., Kramer, L., Bloss, W., Vu, T., Sun, Y., Xu, W., Yue, S., Ren, L., Acton, W. J. F., Hewitt, C. N., Wang, X., Fu, P., and Heard, D. E.: Elevated levels of $\mathrm{OH}$ observed in haze events during wintertime in central Beijing, Atmos. Chem. Phys., 20, 14847-14871, https://doi.org/10.5194/acp-20-14847-2020, 2020.

Squires, F. A., Nemitz, E., Langford, B., Wild, O., Drysdale, W. S., Acton, W. J. F., Fu, P., Grimmond, C. S. B., Hamilton, J. F., Hewitt, C. N., Hollaway, M., Kotthaus, S., Lee, J., Metzger, S., Pingintha-Durden, N., Shaw, M., Vaughan, A. R., Wang, X., Wu, R., Zhang, Q., and Zhang, Y.: Measurements of traffic-dominated pollutant emissions in a Chinese megacity, Atmos. Chem. Phys., 20, 8737-8761, https://doi.org/10.5194/acp20-8737-2020, 2020.

Tan, Z., Fuchs, H., Lu, K., Hofzumahaus, A., Bohn, B., Broch, S., Dong, H., Gomm, S., Häseler, R., He, L., Holland, F., Li, X., Liu, Y., Lu, S., Rohrer, F., Shao, M., Wang, B., Wang, M., Wu, Y., Zeng, L., Zhang, Y., Wahner, A., and Zhang, Y.: Radical chemistry at a rural site (Wangdu) in the North China Plain: observation and model calculations of $\mathrm{OH}, \mathrm{HO}_{2}$ and $\mathrm{RO}_{2}$ radicals, Atmos. Chem. Phys., 17, 663-690, https://doi.org/10.5194/acp17-663-2017, 2017.

Tan, Z., Lu, K., Hofzumahaus, A., Fuchs, H., Bohn, B., Holland, F., Liu, Y., Rohrer, F., Shao, M., Sun, K., Wu, Y., Zeng, 
L., Zhang, Y., Zou, Q., Kiendler-Scharr, A., Wahner, A., and Zhang, Y.: Experimental budgets of $\mathrm{OH}, \mathrm{HO}_{2}$, and $\mathrm{RO}_{2}$ radicals and implications for ozone formation in the Pearl River Delta in China 2014, Atmos. Chem. Phys., 19, 7129-7150, https://doi.org/10.5194/acp-19-7129-2019, 2019.

Tan, Z. F., Hofzumahaus, A., Lu, K. D., Brown, S. S., Holland, F., Huey, L. G., Kiendler-Scharr, A., Li, X., Liu, X. X., Ma, N., Min, K. E., Rohrer, F., Shao, M., Wahner, A., Wang, Y. H., Wiedensohler, A., Wu, Y. S., Wu, Z. J., Zeng, L. M., Zhang, Y. H., and Fuchs, H.: No Evidence for a Significant Impact of Heterogeneous Chemistry on Radical Concentrations in the North China Plain in Summer 2014, Environ. Sci. Technol., 54, 5973-5979, https://doi.org/10.1021/acs.est.0c00525, 2020.

Wang, S. N., Wu, R. R., Berndt, T., Ehn, M., and Wang, L. M.: Formation of Highly Oxidized Radicals and Multifunctional Products from the Atmospheric Oxidation of Alkylbenzenes, Environ. Sci. Technol., 51, 8442-8449, https://doi.org/10.1021/acs.est.7b02374, 2017.

Wang, T., Ding, A. J., Gao, J., and Wu, W. S.: Strong ozone production in urban plumes from Beijing, China, Geophys. Res. Lett., 33, L21806, https://doi.org/10.1029/2006g1027689, 2006.

Wang, T., Nie, W., Gao, J., Xue, L. K., Gao, X. M., Wang, X. F., Qiu, J., Poon, C. N., Meinardi, S., Blake, D., Wang, S. L., Ding, A. J., Chai, F. H., Zhang, Q. Z., and Wang, W. X.: Air quality during the 2008 Beijing Olympics: secondary pollutants and regional impact, Atmos. Chem. Phys., 10, 7603-7615, https://doi.org/10.5194/acp-10-7603-2010, 2010.

Wang, T., Xue, L. K., Brimblecombe, P., Lam, Y. F., Li, L., and Zhang, L.: Ozone pollution in China: A review of concentrations, meteorological influences, chemical precursors, and effects, Sci. Total Environ., 575, 1582-1596, https://doi.org/10.1016/j.scitotenv.2016.10.081, 2017.

Whalley, L. K., Edwards, P. M., Furneaux, K. L., Goddard, A., Ingham, T., Evans, M. J., Stone, D., Hopkins, J. R., Jones, C. E., Karunaharan, A., Lee, J. D., Lewis, A. C., Monks, P. S., Moller, S. J., and Heard, D. E.: Quantifying the magnitude of a missing hydroxyl radical source in a tropical rainforest, Atmos. Chem. Phys., 11, 7223-7233, https://doi.org/10.5194/acp11-7223-2011, 2011.
Whalley, L. K., Blitz, M. A., Desservettaz, M., Seakins, P. W., and Heard, D. E.: Reporting the sensitivity of laser-induced fluorescence instruments used for $\mathrm{HO}_{2}$ detection to an interference from $\mathrm{RO}_{2}$ radicals and introducing a novel approach that enables $\mathrm{HO}_{2}$ and certain $\mathrm{RO}_{2}$ types to be selectively measured, Atmos. Meas. Tech., 6, 3425-3440, https://doi.org/10.5194/amt-6-3425-2013, 2013.

Whalley, L. K., Stone, D., Bandy, B., Dunmore, R., Hamilton, J. F., Hopkins, J., Lee, J. D., Lewis, A. C., and Heard, D. E.: Atmospheric $\mathrm{OH}$ reactivity in central London: observations, model predictions and estimates of in situ ozone production, Atmos. Chem. Phys., 16, 2109-2122, https://doi.org/10.5194/acp16-2109-2016, 2016.

Whalley, L. K., Stone, D., Dunmore, R., Hamilton, J., Hopkins, J. R., Lee, J. D., Lewis, A. C., Williams, P., Kleffmann, J., Laufs, S., Woodward-Massey, R., and Heard, D. E.: Understanding in situ ozone production in the summertime through radical observations and modelling studies during the Clean air for London project (ClearfLo), Atmos. Chem. Phys., 18, 2547-2571, https://doi.org/10.5194/acp-18-2547-2018, 2018.

Woodward-Massey, R., Slater, E. J., Alen, J., Ingham, T., Cryer, D. R., Stimpson, L. M., Ye, C., Seakins, P. W., Whalley, L. K., and Heard, D. E.: Implementation of a chemical background method for atmospheric $\mathrm{OH}$ measurements by laserinduced fluorescence: characterisation and observations from the UK and China, Atmos. Meas. Tech., 13, 3119-3146, https://doi.org/10.5194/amt-13-3119-2020, 2020.

Xue, L. K., Saunders, S. M., Wang, T., Gao, R., Wang, X. F., Zhang, Q. Z., and Wang, W. X.: Development of a chlorine chemistry module for the Master Chemical Mechanism, Geosci. Model Dev., 8, 3151-3162, https://doi.org/10.5194/gmd-8-3151-2015, 2015.

Zhou, W., Zhao, J., Ouyang, B., Mehra, A., Xu, W., Wang, Y., Bannan, T. J., Worrall, S. D., Priestley, M., Bacak, A., Chen, Q., Xie, C., Wang, Q., Wang, J., Du, W., Zhang, Y., Ge, X., Ye, P., Lee, J. D., Fu, P., Wang, Z., Worsnop, D., Jones, R., Percival, C. J., Coe, H., and Sun, Y.: Production of $\mathrm{N}_{2} \mathrm{O}_{5}$ and $\mathrm{ClNO}_{2}$ in summer in urban Beijing, China, Atmos. Chem. Phys., 18, 11581-11597, https://doi.org/10.5194/acp-18-11581-2018, 2018. 